\title{
Nitrogen processes in aquatic ecosystems
}

Book or Report Section

Accepted Version

Durand, P., Breuer, L., Johnes, P. J., Billen, G., Butturini, A., Pinay, G., van Grinsven, H., Garnier, J., Rivett, M., Reay, D. S., Curtis, C., Siemens, J., Maberly, S., Kaste, O., Humborg, C., Loeb, R., de Klein, J., Hejzlar, J., Skoulikidis, N., Kortelainen, P., Lepisto, A. and Wright, R. (2011) Nitrogen processes in aquatic ecosystems. In: Sutton, M. A., Howard, C. M., Erisman, J. W., Billen, G., Bleeker, A., Grennfelt, P., van Grinsven, H. and Grizzetti, B. (eds.) European Nitrogen Assessment. Cambridge University Press, Cambridge, pp. 126-146. ISBN 9781107006126 Available at https://centaur.reading.ac.uk/20855/

It is advisable to refer to the publisher's version if you intend to cite from the work. See Guidance on citing.

Publisher: Cambridge University Press

All outputs in CentAUR are protected by Intellectual Property Rights law, including copyright law. Copyright and IPR is retained by the creators or other copyright holders. Terms and conditions for use of this material are defined in the End User Agreement. 


\section{CentAUR}

Central Archive at the University of Reading

Reading's research outputs online 


\title{
Chapter \\ Nitrogen processes in aquatic ecosystems
}

\author{
Lead authors: Patrick Durand, Lutz Breuer and Penny J. Johnes \\ Contributing authors: Gilles Billen, Andrea Butturini, Gilles Pinay, Hans van Grinsven, \\ Josette Garnier, Michael Rivett, David S. Reay, Chris Curtis, Jan Siemens, \\ Stephen Maberly, Oeyvind Kaste, Christoph Humborg, Roos Loeb, Jeroen de Klein, \\ Josef Hejzlar, Nikos Skoulikidis, Pirkko Kortelainen, Ahti Lepisto and Richard Wright
}

\section{Executive summary}

\section{Nature of the problem (science/management/policy)}

- Freshwater ecosystems play a key role in the European nitrogen $(\mathrm{N})$ cycle, both as a reactive agent that transfers, stores and processes $\mathrm{N}$ loadings from the atmosphere and terrestrial ecosystems, and as a natural environment severely impacted by the increase of these loadings.

\section{Approaches}

- This chapter is a review of major processes and factors controlling $\mathrm{N}$ transport and transformations for running waters, standing waters, groundwaters and riparian wetlands.

\section{Key findings/state of knowledge}

- The major factor controlling $\mathrm{N}$ processes in freshwater ecosystems is the residence time of water, which varies widely both in space and in time, and which is sensitive to changes in climate, land use and management.

- The effects of increased $\mathrm{N}$ loadings to European freshwaters include acidification in semi-natural environments, and eutrophication in more disturbed ecosystems, with associated loss of biodiversity in both cases.

- An important part of the nitrogen transferred by surface waters is in the form of organic N, as dissolved organic N (DON) and particulate organic N (PON). This part is dominant in semi-natural catchments throughout Europe and remains a significant component of the total $\mathrm{N}$ load even in nitrate enriched rivers.

- In eutrophicated standing freshwaters $\mathrm{N}$ can be a factor limiting or co-limiting biological production, and control of both $\mathrm{N}$ and phosphorus (P) loading is often needed in impacted areas, if ecological quality is to be restored.

\section{Major uncertainties/challenges}

- The importance of storage and denitrification in aquifers is a major uncertainty in the global $\mathrm{N}$ cycle, and controls in part the response of catchments to land use or management changes. In some aquifers, the increase of $\mathrm{N}$ concentrations will continue for decades even if efficient mitigation measures are implemented now.

- Nitrate retention by riparian wetlands has often been highlighted. However, their use for mitigation must be treated with caution, since their effectiveness is difficult to predict, and side effects include increased DON emissions to adjacent open waters, $\mathrm{N}_{2} \mathrm{O}$ emissions to the atmosphere, and loss of biodiversity.

- In fact, the character and specific spatial origins of DON are not fully understood, and similarly the quantitative importance of indirect $\mathrm{N}_{2} \mathrm{O}$ emissions from freshwater ecosystems as a result of $\mathrm{N}$ leaching losses from agricultural soils is still poorly known at the regional scale.

- These major uncertainties remain due to the lack of adequate monitoring (all forms of $\mathrm{N}$ at a relevant frequency), especially - but not only - in the southern and eastern EU countries.

\section{Recommendations (research/policy)}

- The great variability of transfer pathways, buffering capacity and sensitivity of the catchments and of the freshwater ecosystems calls for site specific mitigation measures rather than standard ones applied at regional to national scale.

- The spatial and temporal variations of the $\mathrm{N}$ forms, the processes controlling the transport and transformation of $\mathrm{N}$ within freshwaters, require further investigation if the role of $\mathrm{N}$ in influencing freshwater ecosystem health is to be better understood, underpinning the implementation of the EU Water Framework Directive for European freshwaters.

The European Nitrogen Assessment, ed. Mark A. Sutton, Clare M. Howard, Jan Willem Erisman, Gilles Billen, Albert Bleeker, Peringe Grennfelt, Hans van Grinsven and Bruna Grizzetti. Published by Cambridge University Press. @ Cambridge University Press 2011, with sections $\odot$ authors/European Union. 


\subsection{Introduction}

The scope of this chapter is to document the extent of knowledge regarding the fate of nitrogen $(\mathrm{N})$ in European freshwater systems (wetlands, standing and running waters, the hyporheic zone and groundwaters). Another aim is to highlight those areas where knowledge is currently sparse and future research is required to underpin the development of sound evidencebased environmental policy for the wide range of nutrient enriched waters across Europe. The key processes and controls of nitrogen turnover in freshwaters are discussed to understand the observed trends and the impacts of these processes on the ecological status and societal value of European freshwaters.

The definition of groundwater used in this chapter includes the vadose zone beyond the reach of the root system of terrestrial vegetation, running waters are considered down to the limit of their tidal influence, wetlands are restricted to riparian areas receiving surface and groundwater but including the hyporheic zone, and standing waters include all freshwater lakes, ponds, pools and reservoirs.

This chapter first describes the main factors controlling nitrogen cycling in freshwater systems, the distribution of $\mathrm{N}$ forms in waters and their origin, and the role of $\mathrm{N}$ in the ecology of those systems. The specific characteristics of $\mathrm{N}$ cycling in different types of freshwater systems are then highlighted.

\subsection{Factors controlling $N$ cycling in freshwaters}

\subsubsection{The water cycle}

Freshwater is defined as water with less than $0.5 \mathrm{~g} / \mathrm{l}$ of dissolved salts. Some $3 \%$ of the water on Earth is freshwater. About two thirds of it is frozen in polar caps and glaciers, most of the remainder is present as groundwater, and only $0.3 \%$ is surface water. Freshwater ecosystems occupy over 3\% of the Earth's surface. In Europe, freshwaters cover 1\% of the surface and wetlands 0.8\% (European Environment Agency, 2005).

The classical figure of the water cycle (Figure 7.1) illustrates that one main feature of aquatic ecosystems is their interconnectivity. Water infiltrating from terrestrial ecosystems recharges groundwater. In flat, low lying areas the groundwater table reaches the surface, determining the extent of wetlands. These wetlands are often located close to the streams or lakes (riparian wetlands). Streams and lakes are fed by groundwater discharge, but also by surface overland flow and subsurface interflow in variable proportions. The direction of fluxes between groundwater, wetlands, streams and lakes varies according to hydrological conditions.

Owing to natural or artificial obstacles to flow, surface waters create standing water bodies that are generally connected to the hydrological network. They can be located at the source of the streams or along the main course, and vary widely in extension and depth. Standing waters also occur in topographic depressions in the landscape including, for example, kettle holes in some post-glacial landscapes which are often less well connected to the running water network. The main hydrological driver is the excess rainfall, defined here as the amount of water available for groundwater recharge or runoff after interception and evapotranspiration. In Europe, this excess rainfall varies from a few $\mathrm{mm} / \mathrm{yr}$ in the driest Mediterranean zones to more than $1000 \mathrm{~mm}$ in North-Western coast. In most of Europe, it is between $150 \mathrm{~mm}$ and $500 \mathrm{~mm}$ (Figure 7.2).

The seasonality of lotic (running water) ecosystems is largely determined by the hydrological regime. In Europe, three major hydrological regimes exists (Figure 7.3): (1) the oceanic temperate regime, with moderate variations in mean rainfall distribution over the year, and increased evapotranspiration during summer, leading to low summer discharge and winter flooding; (2) the Mediterranean regime with low rainfall and high evapotranspiration in summer leading to extremely low summer discharge and flooding in spring and autumn; and (3) the snowmelt controlled regime (mountainous and Nordic regions) with high discharge during spring or early summer. The first two regimes are characterized by low discharge during the periods with the highest temperature and light intensity, while in the snowmelt regime, the most productive period occurs before the summer flood, under sub-optimal light and temperature conditions.

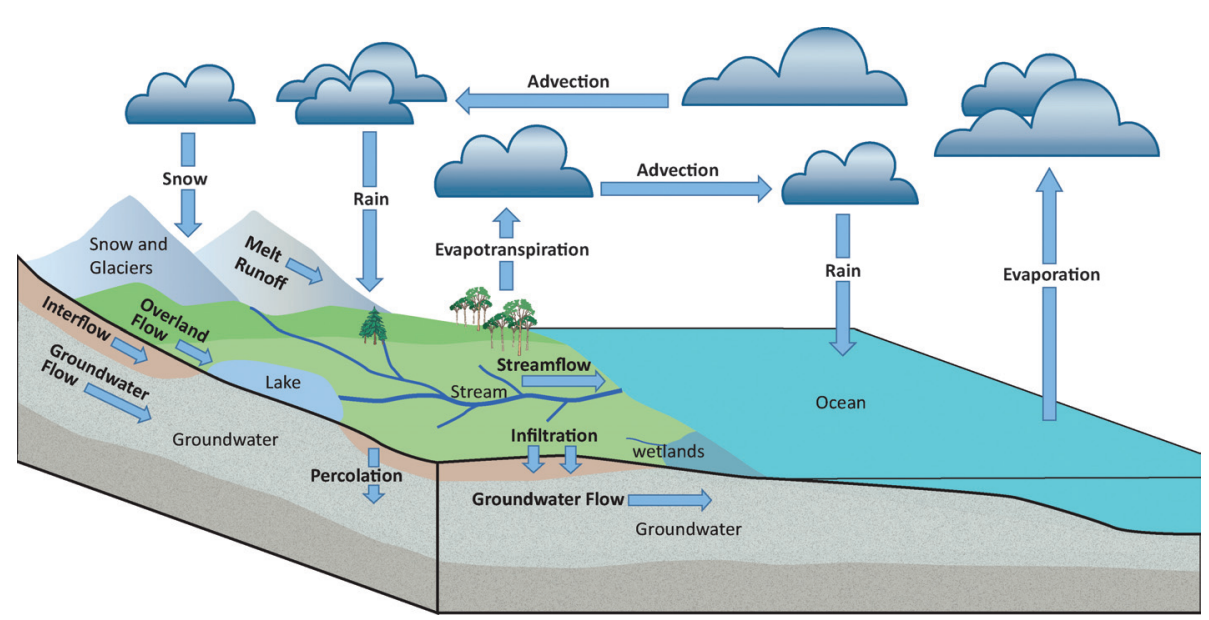

Figure 7.1 The global water cycle (courtesy of Sandra Süß). 


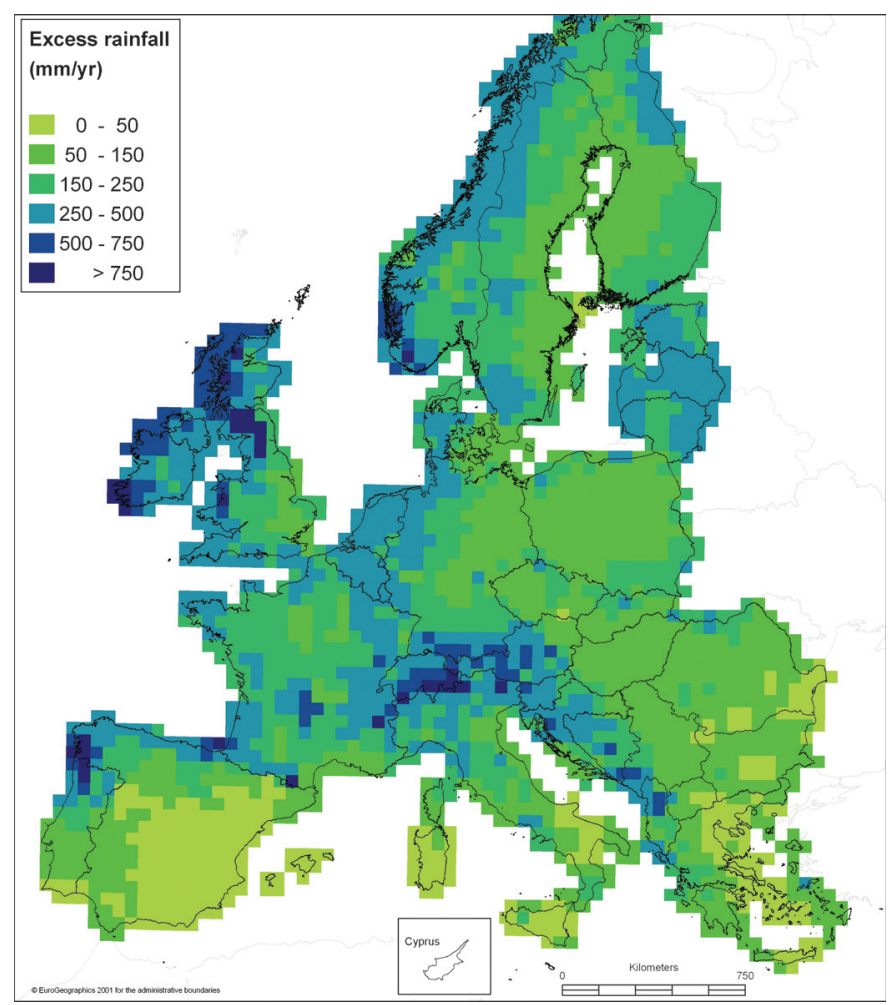

Figure 7.2 Map of excess rainfall in Europe, based on long term rainfall data and computed actual evapotranspiration (Mulligan et al. 2006) (๔ 2006, JRC, European Commission)

\subsubsection{Stream order}

The fate of nitrogen in freshwater depends strongly on the stream network geometry, which can be described in a synthetic and meaningful way by the stream order concept.

The Strahler stream order system (Strahler, 1952) was proposed to define stream sizes based on a hierarchy of tributaries. Headwaters are first-order streams. When two first-order streams connect they form a second-order stream and so forth. The ecological functioning of water bodies, and therefore the $\mathrm{N}$ cycling, varies according to Strahler's order as follows.

Streams of Strahler's order 1 to 3 are characterized by shallow depth and narrow width, steep slope and a relatively high contribution of lateral inputs of water with respect to the volume of the reach. Most inputs of energy are in the form of coarse organic material from riparian vegetation. Shading by riparian trees is common in these reaches, limiting light availability for stream flora. The overall metabolism of the system is typically heterotrophic, dominated by fungi and shredder invertebrates.

Mid-reach river systems are wider, deeper and less strongly influenced by dilution. They receive more light so that autochthonous primary production can occur either through macrophyte (typically stream order 4-5) or planktonic (typically stream order 5-7) development. The overall metabolism of the system becomes autotrophic. Organic matter, either of autochthonous origin or transferred from upstream systems, is dominated by fine particulate organic material and supports a community of collector or grazer invertebrates.
Lower reach systems (stream order $>7$ ) are still deeper and wider. They are no longer influenced by substantial lateral hydraulic dilution and show a decline of autochthonous primary production because of increased depth and turbidity which limits primary production capacity. They are again often heterotrophic, with stream metabolism strongly dependent on organic material brought in from upstream reaches. Sedimentation of fine material is possible and sediments are often rich in organic material.

\subsubsection{Residence times}

In all aquatic ecosystems, $\mathrm{N}$ cycling is controlled by the energy sources (light, organic matter and reduced inorganic compounds such as sulphur (S) or ferrous minerals), redox conditions (oxygen availability) and the nutrient loads. The main factor differentiating $\mathrm{N}$ turnover rates in the different types of freshwater systems, however, is the residence time of the water. The mean residence time of a well mixed reservoir is defined as the ratio between the volume of water $(\mathrm{V})$ and the flux that goes through it $(\mathrm{Q})$. Depending on the lines of flux, the actual residence time may vary considerably within a given water body: for example, in groundwater and lakes the residence time increases with depth, and in streams it is higher near the banks and the bed than in the middle of the stream. For running waters residence times are often defined for reaches (the portion of the stream between two confluences). For lakes and wetlands, residence time may be very short along the primary flow channels, but very long in areas less well connected to the primary flow channels. This is particularly evident in lakes formed over flooded river valleys, and in wetlands with a clear point of inflow and outflow.

Typical residence times increase from order 1 streams (minutes to hours) to larger streams and wetlands (weeks), standing waters (weeks to decades) and groundwaters (decades to centuries). The highest variability in residence time is found in standing waters (from days to decades) and for groundwater (from months to thousands of years). Residence time also varies over time within a system. Bearing in mind the general definition of residence time as $\mathrm{V} / \mathrm{Q}$, since the flux is far more variable than the volume, the variability of residence time is controlled by the variations in discharge from the catchment. Therefore, rivers with low flows in summer have residence times similar to riverine lakes, and numerous lakes and wetlands are subjected to flushing episodes during high flow events.

\subsubsection{Nitrogen delivery to freshwaters}

Nitrogen can reach freshwaters through a number of pathways: by atmospheric deposition on the catchment or directly on the water body; by leaching from diffuse sources within the catchment, such as those resulting from fertiliser and manure application; by sediment erosion of $\mathrm{N}$ rich soils and surface applications of manure in catchments; and by direct input from point sources such as sewage treatment works. A further source of reactive $\mathrm{N}\left(\mathrm{N}_{\mathrm{r}}\right)$ is nitrogen fixation. Some prokaryotes, such as some cyanobacteria, also possess the nitrogenase enzyme that allows atmospheric nitrogen to be converted into ammonia 
River Seine
Oceanic temperate

Mediterranean

River Ardèche
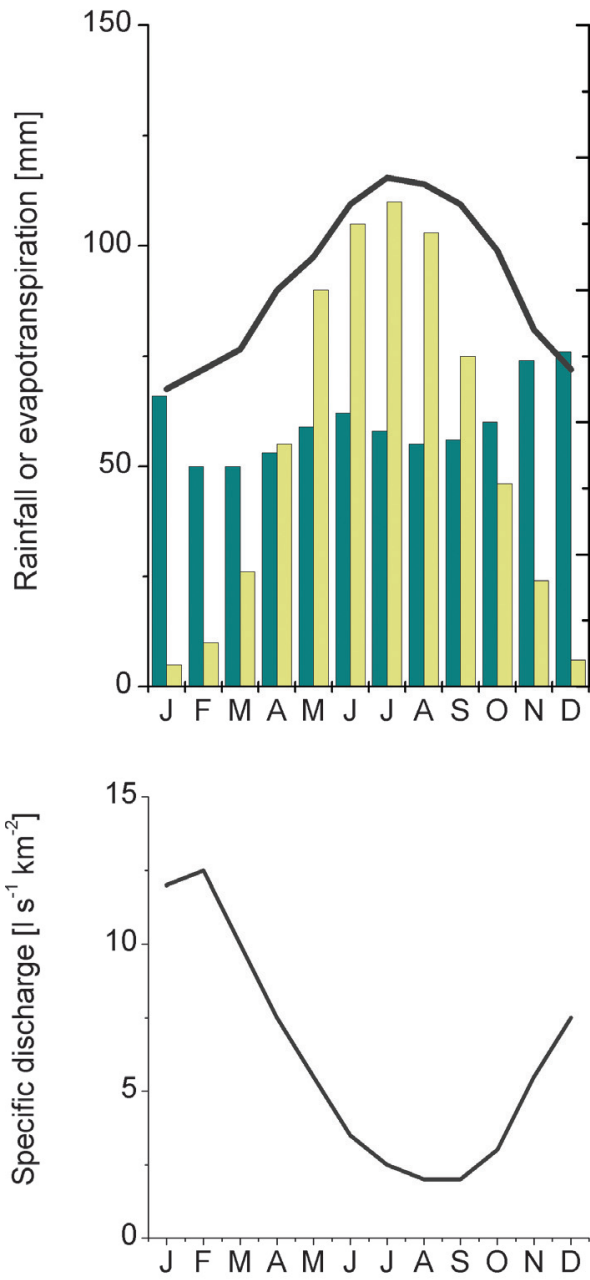

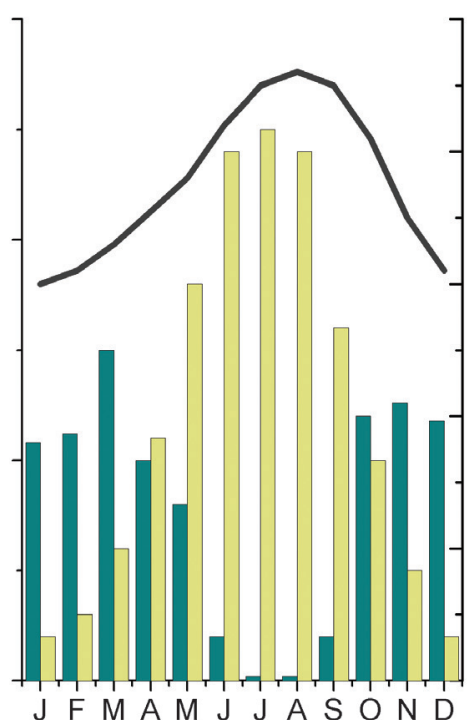

Nordic

River Kalix
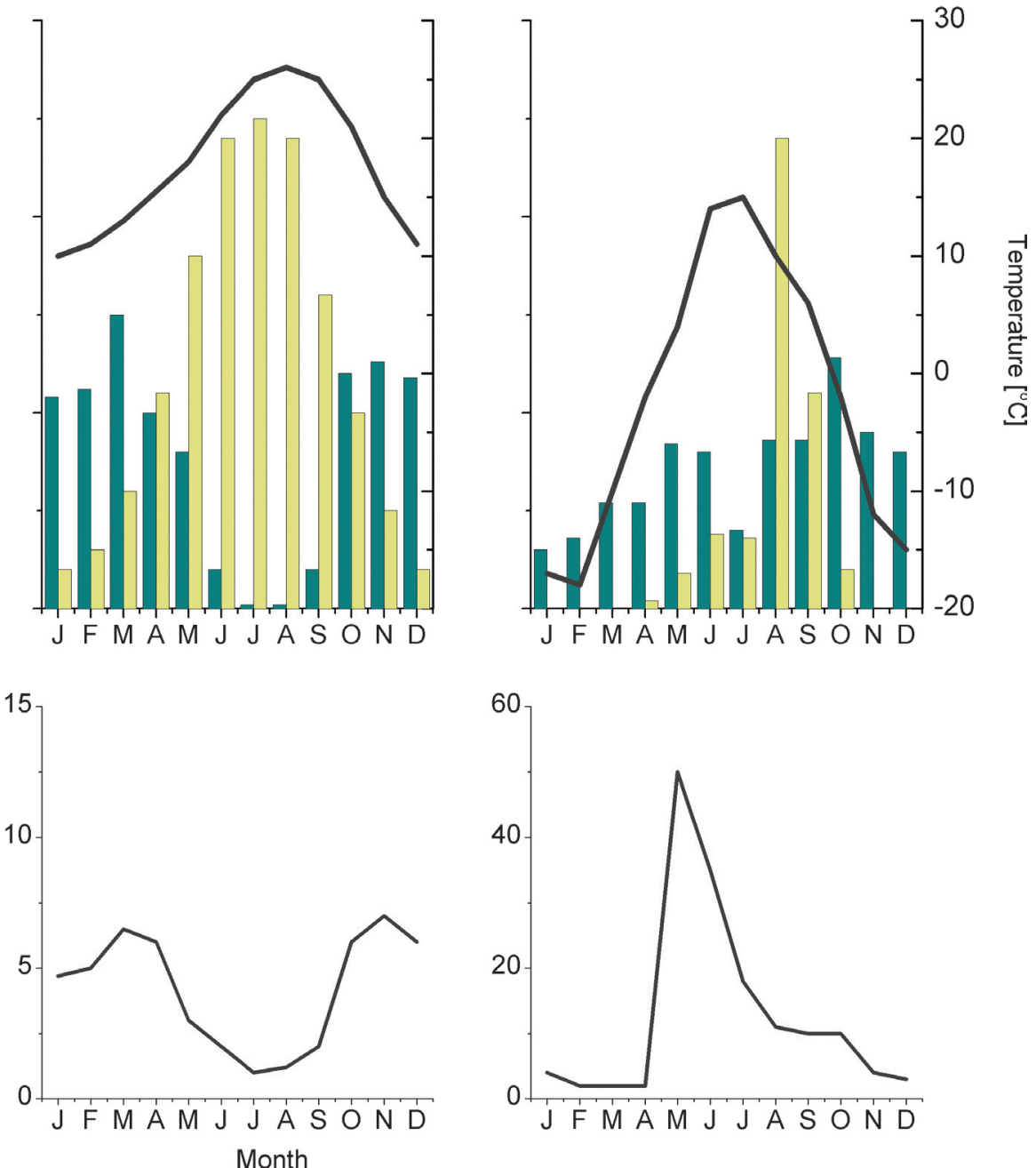

Figure 7.3 Examples of the three major hydrological regimes of European rivers. Blue bars: rainfall; yellow bars: evapotranspiration; brown lines: temperature: dark lines: specific discharge.

and thus can exploit dissolved nitrogen gas in freshwaters. A few freshwater diatoms such as Epithemia and Rhapalodia also possess this ability via endosymbiotic inclusions believed to be derived from a cyanobacterium related to Cyanothece (Prechtl et al., 2004), although this mechanism is not widely found in European freshwaters.

The nutrient load delivered to aquatic ecosystems from diffuse catchment and atmospheric sources depends strongly on the hydrological processes, particularly the relative importance of different water pathways in the transfer of the various $\mathrm{N}$ forms from terrestrial to aquatic systems (Figure 7.4).

Overland flow is responsible for the transport of particulate forms of $\mathrm{N}$ and, to a lesser extent, of dissolved organic $\mathrm{N}$ (DON) and ammonium. In agricultural areas, dissolved inorganic $\mathrm{N}$ (DIN) concentrations in overland flow are usually low compared to those of subsurface water, causing dilution of DIN in streamwater during flood events (Durand and Juan Torres, 1996; Durand et al., 1999; Kemp and Dodds 2001). This is not always true in situations where subsurface waters are low in DIN and where surface accumulation of $\mathrm{N}$ occurs, for example: during snowmelt events when atmospheric $\mathrm{N}$ deposition has accumulated in the snowpack; shortly after fertilizer applications; in intensively farmed outdoor stock enterprises; in Mediterranean forested zones during floods (Bernal et al., 2006; Johnes, 2007a).

Most $\mathrm{N}$ leaving the soil in the form of nitrate will be transported to adjacent water bodies by water that has infiltrated in the soil, but the conditions controlling this transfer vary depending on the relative importance of shallow pathways (interflow, return flow, shallow groundwater seepage) and of deep infiltration (Creed et al., 1996; Molenat et al., 2002). DON is mostly delivered during storm events, with $\mathrm{N}$-rich soil porewater flushed to the hyporheic zone and adjacent surface waters. Less DON is transported to groundwater stores in permeable areas with deep aquifers, where the pathway is dominated by nitrate flux. In these areas unsaturated vertical flow can be very long and lead to significant accumulation of nitrate in the vadose zone. The temporal variation of nitrate fluxes 


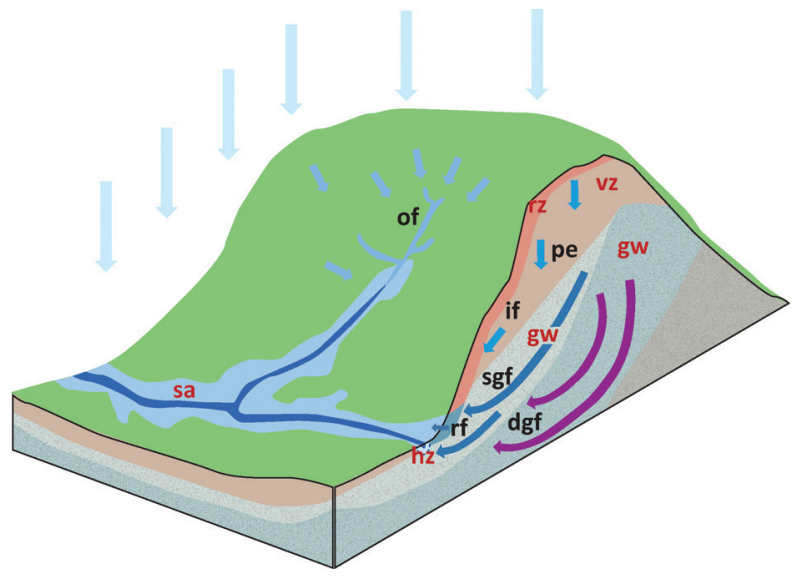

legend:

rz: root zone vz: vadose zone hz: hyporheic zone gw: groundwater sa: saturated area

of: overland flow pe: percolation if: interflow

rf: return flow (exfiltration) sgf: shallow groundwater flow dgf: deep groundwater flow
Figure 7.4 Schematic of the different flows in a headwater catchment. The colours of the arrows symbolize the age of water from the most recent (light blue) to the oldest (purple) (courtesy of Sandra Süß). from groundwater to rivers is damped, and the mean residence time of water and solutes in these areas can be in the order of several decades (Wade et al., 2006).

\subsection{Nitrogen forms and sources in fresh water}

\subsubsection{Particulate and dissolved N components}

Nitrogen cycling in aquatic ecosystems is complex and involves a variety of $\mathrm{N}$ forms and associated oxidation states. Both the oxidized and reduced inorganic $\mathrm{N}$ species $\left(\mathrm{NO}_{2}^{-}, \mathrm{NO}_{3}^{-}, \mathrm{NH}_{4}^{+}\right.$, $\mathrm{NH}_{3}$ ) and organic $\mathrm{N}$ fractions (DON, PON) are commonly found in all freshwater, estuarine and coastal waters across Europe. Nitrate, nitrite, ammonium and DON are directly available for plant uptake, supporting production in both the algal and higher plant communities. In addition the gaseous forms $\left(\mathrm{N}_{2}, \mathrm{~N}_{2} \mathrm{O}, \mathrm{NO}\right)$ are exchanged with the atmosphere.

$\mathrm{N}$ speciation in streams varies along a gradient of $\mathrm{N}$ enrichment. Nitrate is the dominant form in highly enriched rivers, whereas DON is the dominant form in less enriched rivers. DON can also be an important secondary constituent of the TN load even in the most enriched rivers.

Figure 7.5 presents nitrogen species concentrations in different European streams ranging from oligotrophic to hypertrophic. Data were collated for the present work from all available national databases and both published and unpublished research on the relative proportion of total $\mathrm{N}$ present in the various $\mathrm{N}$ species forms in European rivers. Data were only included where at least the inorganic $\mathrm{N}$ species and total $\mathrm{N}$ had been determined at high sampling frequency (typically weekly to daily sampling frequency). For some sites only total organic N (TON) concentrations were reported (shown yellow on Figure 7.5) alongside inorganic N species concentrations. For the majority of sites, however, the full species range had been determined, including both DON and PON fractions. A total of 84 separate annual records for 57 streams were found which fulfilled these criteria. Data have been plotted along a gradient of increasing total $\mathrm{N}$ concentrations, from the lowest concentrations typically found in boreal headwater streams to the highest concentrations found in rivers draining the intensively farmed lowland regions of Europe (Figure 7.5).

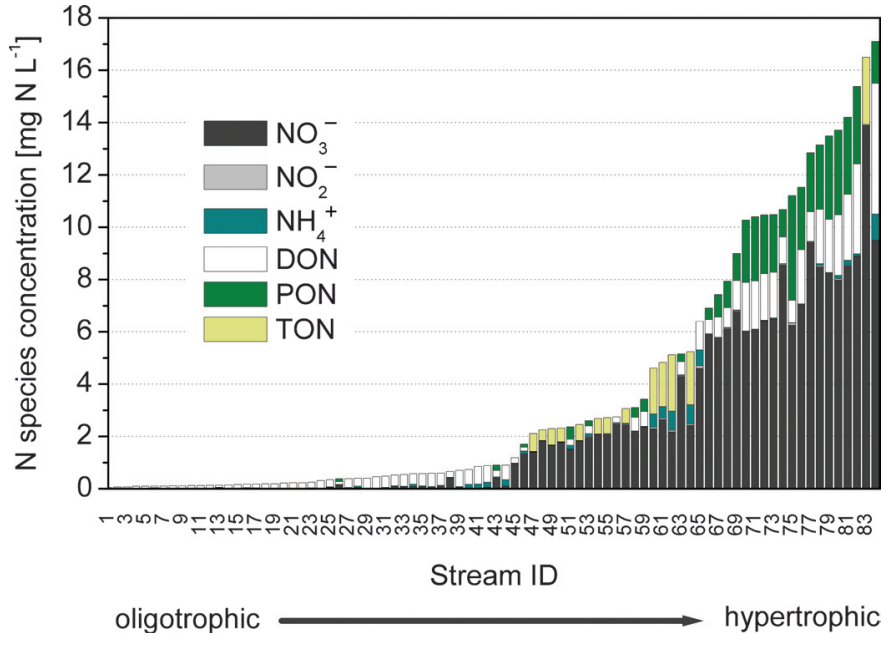

Figure 7.5 Concentrations of $\mathrm{N}$ species in 57 European streams and rivers (an explanation of data sources is given in the text. Stream ID, sampling locations and observation periods are provided in the Supplementary Material Section 7)

Two clear patterns emerge from Figure 7.5: nitrate concentrations increase in absolute terms and also as a proportion of total $\mathrm{N}$ along a gradient from ultra-oligotrophic to hyper-trophic waters, and mean annual DON concentrations also increase along this gradient but as a decreasing proportion of total $\mathrm{N}$. Concentrations of nitrate range from $<0.002$ $\mathrm{mg} \mathrm{NO}_{3}{ }^{-} \mathrm{N} / \mathrm{l}$ in the least disturbed catchments to over $14 \mathrm{mg}$ $\mathrm{NO}_{3}{ }^{-}-\mathrm{N} / 1$ in the most intensively farmed catchments. DON concentrations are initially substantially higher than nitrate concentrations in undisturbed sites, with mean annual DON concentrations ranging from $<0.15 \mathrm{mg} \mathrm{N} / \mathrm{l}$ in low nutrient status upland waters (Willetts et al., 2004; Kortelainen et al., 2006; Skoulikidis and Amaxidis 2009) to over $3 \mathrm{mg} \mathrm{N} / \mathrm{l}$ in the highly enriched rivers of lowland Britain and the Netherlands, and a maximum of $5 \mathrm{mg} \mathrm{N} / \mathrm{l}$ in the River Ter in Spain, with maximum daily concentrations in excess of $9 \mathrm{mg} \mathrm{N} / \mathrm{l}$ (Johnes and Burt 1991). This pattern, with nitrate concentrations increasing at a proportionally higher rate than DON concentrations as nutrient enrichment occurs is highlighted in Figure 7.6.

Ultra-oligotrophic systems, where total $\mathrm{N}$ concentrations are less than $1 \mathrm{mg} \mathrm{N} / \mathrm{l}$, are highly $\mathrm{N}$ limited, and inorganic $\mathrm{N}$ is taken up rapidly by the biota to sustain production. DON, 

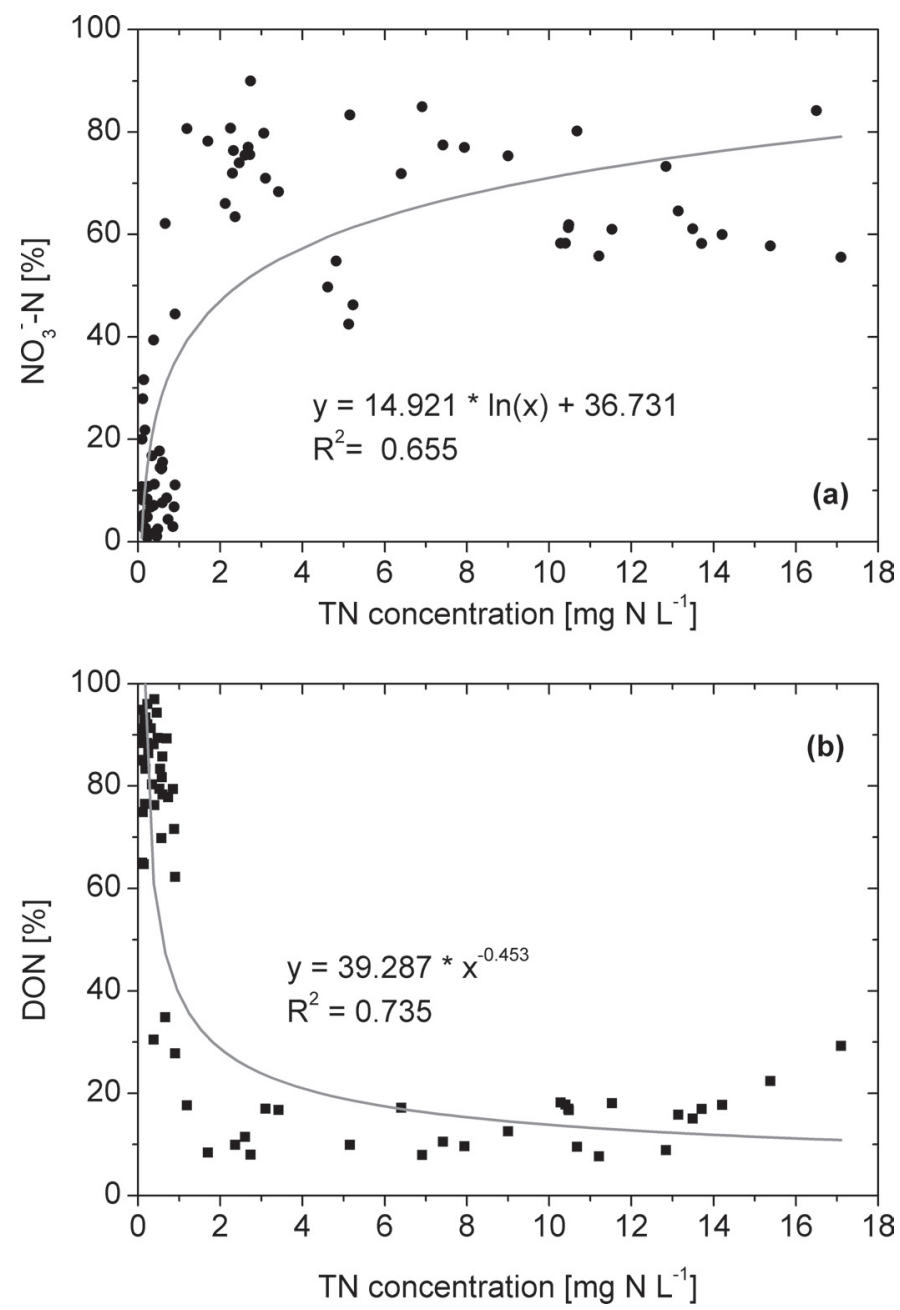

Figure 7.6 Proportion of total $\mathrm{N}$ present in the form of (a) nitrate- $\mathrm{N}$ and (b) DON in European rivers along a gradient of $\mathrm{N}$ enrichment (an explanation of data sources is given in the text).

as a by-product of microbial breakdown of organic matter, is released to adjacent waters through flushing of soil porewaters during and after rainfall, providing a substrate for microbial metabolism in situ and a mechanism for $\mathrm{N}$ transport downstream. In these systems, DON typically constitutes over $60 \%$ of total N, and nitrate concentrations are typically less than $40 \%$ of total $\mathrm{N}$. Above $1 \mathrm{mg} \mathrm{N} / \mathrm{l}$ there is surplus inorganic $\mathrm{N}$ being introduced to the system as a result of increasing anthropogenic disturbance of the catchment and/or increasing atmospheric $\mathrm{N}$ deposition rates. These increasingly productive systems often generate more DON which, together with background DON, is flushed downstream together with surplus inorganic $\mathrm{N}$ leached from $\mathrm{N}$ enriched agricultural and forest soils, or delivered from point source sewage discharges and intensive livestock enterprises. This leads to a rising trend in DON concentrations, but a decrease in the proportion of total $\mathrm{N}$ in the form of DON; and a rising trend in nitrate concentrations with an associated increase in the proportion of total $\mathrm{N}$ in the form of nitrate. Thus, as catchments become enriched through anthropogenic enhancement of $\mathrm{N}$ inputs, the system becomes less efficient at processing these inputs, and as system inefficiency rises, inorganic $\mathrm{N}$ concentrations rise disproportionately.
In lowland, intensively farmed agricultural catchments DON contributes up to $30 \%$ of the total N load, with up to $90 \%$ contributed in the form of nitrate. In upland waters, with lower $\mathrm{TN}$ loading rates, and a higher proportion of histosol soils in their catchments, the DON fraction can constitute up to $90 \%$ of the TN load (Kortelainen et al., 1997; Willetts et al., 2004). Overall in European streams, between 10 and $80 \%$ of the total $\mathrm{N}$ load, and 11 to $100 \%$ of the total dissolved $\mathrm{N}$ load may be in the form of DON (Mattsson et al., 2009), for which no specific European legislation exists. DON is also not determined in most European routine water quality monitoring programmes. Evidence from a range of sources indicating a rising trend in dissolved organic carbon (DOC) concentrations in many upland waters (Evans et al., 2005), possibly due to climate change, raises additional concerns since a rise in DON concentrations could also be expected.

There is evidence from experimental and field monitoring studies that low molecular weight DON (amino acids, polyamines) is directly available for plant and algal uptake, and is a key resource in $\mathrm{N}$ limited oligo- to mesotrophic estuaries and freshwaters (Maberly et al., 2002; Fong et al., 2004). Further experimental data show that both PON and high molecular weight DON are available for microbial assimilation in both terrestrial and aquatic environments (Antia et al., 1991; Chapin et al., 1993; Seitzinger and Sanders, 1997; Lipson and Näsholm, 2001; Jones et al., 2005). Further, PON can act as a food resource for aquatic filter-feeding organisms, and as an important component of $\mathrm{C}$ metabolism in aquatic ecosystems. Both DON and PON provide a key pathway for nitrogen transfer downstream, playing an important role in sustaining the nutrient spiral within rivers, lakes, estuaries and wetlands.

Point sources of nitrogen, including discharges from industrial sources, sewage treatment works and overflow of septic tank systems can be locally significant as sources of $\mathrm{N}$ loading to adjacent waters, but are rarely significant contributors to the total $\mathrm{N}$ loading delivered to waters from their catchments where atmospheric deposition and agriculture are fully taken into account. These are the primary sources of $\mathrm{N}$ enrichment of European waters (Moss et al., 1996; Johnes and Butterfield 2002). For EU 27, total N excretion by livestock in 2000 was about the same as total fertilizer use (Oenema et al., 2007). Particular problems exist with intensive agricultural regions where heavily fertilized grassland and high stocking densities have lead to excessive $\mathrm{N}$ loading to these components of the terrestrial ecosystem. It is also a problem in many upland areas of Europe where stocking densities have risen on marginal land with steep slopes, thin soils and high rates of rainfall and snowmelt where the intrinsic nutrient export potential is high. The apportionment of $\mathrm{N}$ sources of nitrogen in the major European catchments is described in more detail in Billen et al., 2011 (Chapter 13 this volume).

\subsubsection{Gaseous N emissions from freshwater ecosystems}

Through the processes of nitrification and denitrification, $\mathrm{N}_{\mathrm{r}}$ input may enhance the biogenic production of the greenhouse 
gas nitrous oxide $\left(\mathrm{N}_{2} \mathrm{O}\right)$ in standing waters like lakes and ponds (Mengis et al., 1997), in wetlands (Johansson et al., 2003) and in groundwaters, streams, and rivers (Seitzinger and Kroeze, 1998; Hasegawa et al., 2000). $\mathrm{N}_{2} \mathrm{O}$ can also be leached directly into these systems, particularly from agricultural soils, producing super-saturation of $\mathrm{N}_{2} \mathrm{O}$ in the soil leachate (Dowdell et al., 1979). Natural aquatic systems are generally considered relatively minor sources of $\mathrm{N}_{2} \mathrm{O}$, e.g. $3 \%-6 \%$ of the direct agricultural emissions in the Seine basin (Garnier et al., 2009). In fact, aquatic systems with low $\mathrm{N}$ availability may act as a sink for $\mathrm{N}_{2} \mathrm{O}$ (Mengis et al., 1997; Blicher-Mathiesen and Hoffmann, 1999; Dhondt et al., 2004). Whether a system acts as a source or a sink depends on local circumstances including the availability of $\mathrm{N}_{\mathrm{r}}$, temperature and $\mathrm{pH}$.

Natural wetlands are likely to be relatively minor sources of $\mathrm{N}_{2} \mathrm{O}$, due to the low availability of $\mathrm{N}_{\mathrm{r}}$ common to these systems (Regina et al., 1996). Relatively high nitrous oxide fluxes have been quantified for constructed and/or riparian wetlands receiving high $\mathrm{N}_{\mathrm{r}}$ inputs. However, the evidence base is incomplete and other authors claim that $\mathrm{N}_{2} \mathrm{O}$ emissions from constructed wetlands are relatively insignificant at the landscape scale (Søvik et al., 2006). There is clearly a need for further research on the role of wetlands at landscape scale, whether natural or constructed, on $\mathrm{N}_{2} \mathrm{O}$ emission rates. Based on measurement and budgeting approaches in the Seine basin, the indirect $\mathrm{N}_{2} \mathrm{O}$ emissions (including the ones from wastewater treatment plants, water mirror, and riparian zones) have been evaluated as $13 \%-17 \%$ of the direct emissions (Garnier et al., 2009). Lakes can be sources of sinks of $\mathrm{N}_{2} \mathrm{O}$, but the importance of $\mathrm{N}_{2} \mathrm{O}$ emissions from lakes also remains poorly quantified. Many lakes have deep anoxic zones that are undersaturated with $\mathrm{N}_{2} \mathrm{O}$ and this is generally considered to be the result of $\mathrm{N}_{2} \mathrm{O}$ consumption by denitrifying bacteria (Mengis et al., 1997). In the oxic zone of lakes, incomplete denitrification can result in super-saturations of $\mathrm{N}_{2} \mathrm{O}$ and subsequent outgassing to the atmosphere. This source may be especially significant in the littoral zone of eutrophic and hyper-eutrophic lakes where variable redox conditions and plentiful supplies of organic carbon (C) lead to increased $\mathrm{N}_{2} \mathrm{O}$ production from nitrification and/or incomplete denitrification (Huttunen et al., 2003).

In headwater streams, emissions are predominantly a result of the physical outgassing of $\mathrm{N}_{2} \mathrm{O}$-supersaturated water entering them via leaching and surface run-off. Such allochthonous $\mathrm{N}_{2} \mathrm{O}$ inputs are generally lost through outgassing within a few hundred meters of entry to open water courses (Garnier et al., 2009). However, emissions of $\mathrm{N}_{2} \mathrm{O}$ from acid upland soils and peats were found to be a negligible proportion of deposition inputs of $\mathrm{N}$ in an intensive study of four headwater moorland catchments in the UK (Curtis et al., 2006). In lowland streams and rivers, in situ production of $\mathrm{N}_{2} \mathrm{O}$ may become more important, with this autochthonous $\mathrm{N}_{2} \mathrm{O}$ being produced via nitrification and denitrification in aquatic sediments and occasionally in the water column (Dong et al., 2004).

Globally, most of the $\mathrm{N}_{2} \mathrm{O}$ emitted from aquatic systems is associated with agriculture (Kroeze et al., 1999; Bouwman et al., 2005). Numerous studies have now reported super-saturation of dissolved $\mathrm{N}_{2} \mathrm{O}$ in agricultural drains, aquifers, streams and rivers (MacMahon and Dennehy, 1999; Hasegawa et al., 2000; Dong et al., 2004; Clough et al., 2006; Beaulieu et al., 2008), but the true importance of $\mathrm{N}_{2} \mathrm{O}$ losses from this indirect' pathway compared to direct emissions from fertilized fields remains an area of considerable uncertainty (Haag and Kaupenjohann, 2001). Clearly more experimental and process-based modelling studies may be needed to better understand the processes underlying $\mathrm{N}_{2} \mathrm{O}$ formation in fresh water systems.

\subsection{The role of $\mathrm{N}$ in freshwater ecosystems}

\subsubsection{Role as a nutrient}

The primary role of $\mathrm{N}$ in freshwater ecosystems is as one of the key nutrients, along with carbon, phosphorus $(\mathrm{P})$ and silica $(\mathrm{Si})$, required to support primary production by higher plants and algae. This process of photoautotrophy requires energy from sunlight and C, N, Si and P. Nitrogen also plays a role in determining the food web structure and relative productivity of any water body through microbial, algal and plant uptake of $\mathrm{N}$ in the form of both inorganic $\mathrm{N}$ species and DON. Any change in the rate of supply of nitrogen to a water body, or the relative abundance of $\mathrm{C}, \mathrm{N}, \mathrm{Si}$ and $\mathrm{P}$, will lead to changes in the productivity of the water body and its microbial metabolism, with associated secondary effects in terms of microbial, plant and animal community species composition and relative abundance, and the structure and balance of the aquatic food web.

The role of $\mathrm{N}$ in freshwater ecosystems is clearly illustrated through examination of the changes to ecosystem structure and function in response to nutrient enrichment. This process is termed eutrophication, defined under the EU Urban Wastewaters Treatment Directive (91/271/EEC) as the enrichment of water by nutrients, especially compounds of nitrogen and/or phosphorus, causing an accelerated growth of algae and higher forms of plant life to produce an undesirable disturbance to the balance of organisms present in the water and to the quality of the water concerned. Typical responses to the eutrophication process can range from losses in biodiversity resulting from shifts in higher plant community species composition and relative abundance; increases in phytoplankton productivity leading, in extreme examples, to dominance of $\mathrm{N}$ fixing cyanobacteria in the primary producer community; and shifts in food web structure. See Grizzetti et al., 2011, (Chapter 17 this volume) for more detail.

In the phytoplankton (algal) community, because of the relative abundance of $\mathrm{C}$ and $\mathrm{N}$ relative to $\mathrm{P}$ in natural surface waters, productivity is most commonly assumed to be limited by the availability of $\mathrm{P}$ rather than $\mathrm{N}$ or $\mathrm{C}$ (Hecky and Kilham, 1988; Huszar et al., 2006). This is based on the application of Liebig's Law of the Minimum', which proposes that the biological response to resource abundance is controlled by the single most limiting resource. However, this is complicated by the interacting effects of ecological factors (Talling, 1979) and because within the phytoplankton community, different species may be limited by different factors (Hecky and Kilham, 1988; Maberly et al., 2002). Consequently, it is likely that more than one nutrient can control the yield or rate of growth even in the phytoplankton community. 
In the higher plant community, rooted macrophytes obtain a large part of their nutrients from the sediment (Barko et al., 1991 ), and $\mathrm{N}$ and $\mathrm{P}$ are required in a ratio of around 30:1 (Duarte, 1992; Verhoeven et al., 1996). Higher plants require almost twice as much $\mathrm{N}$ as phytoplankton, relative to $\mathrm{P}$. In the sediment and the sediment porewater the availability of $\mathrm{P}$ is much higher than in the surface water, particularly in nutrient enriched systems, and in contrast to N. Accordingly, rooted and benthic species experience a higher $\mathrm{P}$ availability than free floating plant species such as Lemna spp, and the free-floating phytoplankton community that derive their nutrient resources from the water column and, in the case of the cyanobacteria, through $\mathrm{N}$ fixation from atmospheric sources. For higher plants, therefore, $\mathrm{N}$ is more likely to be limiting to productivity than $\mathrm{P}$, and this is confirmed by a number of research studies (Anderson and Kalff, 1986; Barko et al., 1988) including recent work which has shown that high $\mathrm{N}$ concentrations seem to be correlated with a low species diversity in the macrophyte community (James et al., 2005) and a low macrophyte abundance in lakes (Gonzalez Sagrario et al., 2005), see also Chapter 17 (Grizzetti et al., 2011, this volume) for more details.

Thus the role of $\mathrm{N}$ and $\mathrm{P}$ in limiting production from oligotrophic to eutrophic status is complex: different elements of the biota respond to $\mathrm{P}$ and $\mathrm{N}$ loads delivered to waters in different ways, mediated by the access of each biotic group to each nutrient store within the water body. Submerged aquatic plants, and benthic algal communities in clear water lakes and streams growing on P-enriched sediments are likely to be N-limited. Emergent plant production along lake and river margins will reflect the relative abundance of $\mathrm{N}$ and $\mathrm{P}$ in the bed and bank sediments. The free-floating phytoplankton community in lakes and slow-flowing lowland river reaches will depend on the relative availability of nutrients in the water column. In all cases, the role of nutrients in limiting biological production may be over-ridden by other factors such as reduced light penetration in turbid and highly coloured waters, or shear stress and abrasion associated with high flow environments. The impact of nitrogen enrichment in European freshwaters is likely, therefore, to lead to changes in community structure and composition, as well as an increase in gross productivity in the system.

\subsubsection{Role in water acidification}

In undisturbed lake and stream catchments, most $\mathrm{N}$ export is in the form of organic N. Spatially representative long term data bases from 21 managed and 42 unmanaged headwater boreal catchments covered by peatlands and forests across Europe, demonstrate that the long term $\mathrm{N}$ load is dominated by organic $\mathrm{N}$ in pristine and managed catchments (Kortelainen et al., 1997; Mattsson et al., 2003; Kortelainen et al., 2006). In northern European lakes and streams, concentrations of inorganic $\mathrm{N}$ are generally very low compared with organic $\mathrm{N}$. The presence of elevated nitrate in undisturbed lake and stream catchments can indicate anthropogenic $\mathrm{N}$ deposition where direct catchment sources are absent (intensive agriculture, industrial or urban areas, point sources). Nitrate may originate as $\mathrm{NO}_{\mathrm{x}}$ or reduced $\mathrm{N}$ (through nitrification) but in either case, leached nitrate in these catchments indicates a net input of acidity. Data from various studies suggest that $\mathrm{NO}_{3}{ }^{-}$concentrations in acidsensitive lakes increased from their very low levels during the 1970s and 1980s (e.g. Grennfelt and Hultberg, 1986; Brown, 1988; Henriksen and Brakke, 1988). Later studies confirmed that nitric acid is making a major contribution to acidification in many parts of Europe and North America (Murdoch and Stoddard, 1992; Allott et al., 1995; Wright et al., 2001).

The resulting decrease of acid neutralizing capacity and $\mathrm{pH}$ can significantly affect the productivity and biodiversity of aquatic ecosystems. Even where acidification is not, or no longer, chronic, episodic acidification e.g. during snowmelt can threaten sensitive biota. Impacts have been reported on a wide range of species, including algae, macrophytes, micro- and macroinvertebrates, batrachians, salmonids and riverine birds (Ormerod and Durance 2009). Acidification can also affect functions such as organic matter decomposition (Merrix et al., 2006).

While total $\mathrm{N}$ deposition is now declining in many parts of Europe, nitrate leaching continues to slow the chemical recovery of freshwaters from acidification, due to $\mathrm{N}$ saturation of the terrestrial ecosystems (Butterbach-Bahl et al., 2011, Chapter 6 this volume). Long-term trends are notoriously difficult to detect for nitrate because nitrate concentrations vary strongly over different timescales, ranging from diurnal and seasonal (Reynolds and Edwards, 1995) to climatically driven variations linked to 5-10 yearly fluctuations in the North Atlantic Oscillation index (Monteith et al., 2000). Furthermore, this overall lack of general trend at the European scale was suggested to be the result of opposing factors: the increasing $\mathrm{N}$ saturation status of catchments in the context of declining $\mathrm{N}$ deposition in some parts of Europe (Wright et al., 2001).

Data from 54 European lake and stream sites included in the ICP Waters Programme (UNECE International Cooperative Programme on Assessment and Monitoring of Acidification of Rivers and Lakes) show that $\mathrm{N}$ concentrations in runoff increase as $\mathrm{N}$ deposition levels rise above certain thresholds (Figure 7.7). At sites with inorganic N (TIN) concentrations in precipitation below $0.25 \mathrm{mg} \mathrm{N} / \mathrm{l}$, runoff TIN concentrations did not exceed $0.1 \mathrm{mg} \mathrm{N} / \mathrm{l}$. This was typically observed at remote sites in Scandinavia and Scotland with natural or semi-natural vegetation cover. In areas with precipitation concentrations in the range of $0.25-0.7 \mathrm{mg} \mathrm{N} / \mathrm{l}$, TIN in runoff reached $0.4 \mathrm{mg}$ $\mathrm{N} / \mathrm{l}$. This included the more polluted locations in Scandinavia together with sites in the Czech Republic, UK, and Italy. Above this deposition level, runoff concentrations spanned a wide range from below $0.3 \mathrm{mg} \mathrm{N} / \mathrm{l}$ to more than $4 \mathrm{mg} \mathrm{N} / \mathrm{l}$. The latter illustrates that catchment TIN losses are highly variable among sites, depending on landscape characteristics, site history and different types of disturbance. Sites included in this group were located in Germany, the Czech Republic and in Italy.

It is clear that reductions in total $\mathrm{N}$ deposition will have to be achieved to further reduce nitrate concentrations in seminatural catchments in Europe. What is not yet known is the degree to which nitrate leaching could increase if deposition levels are held constant. Recent evidence from an analysis of 20 years of data in the UK Acid Waters Monitoring Network shows 


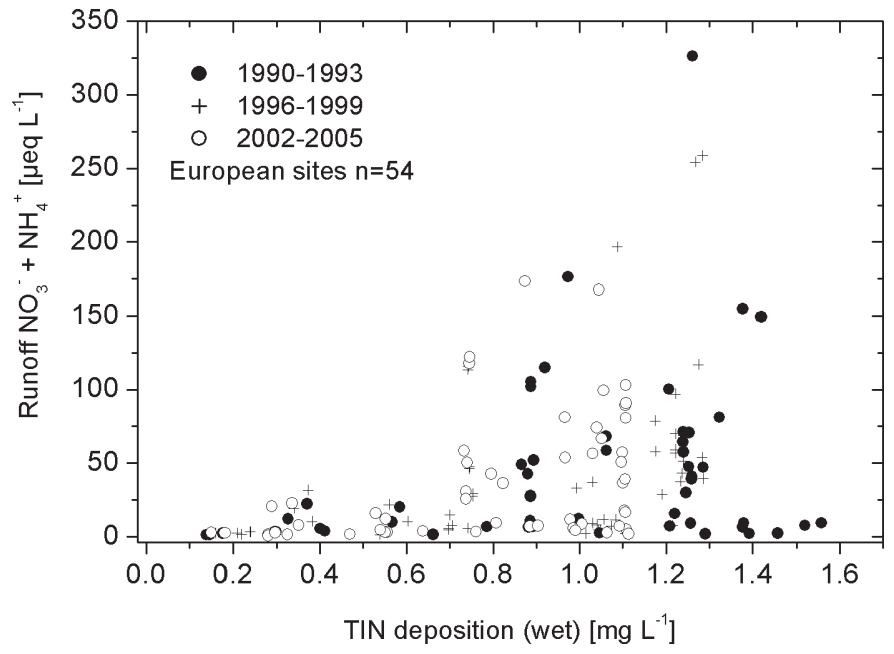

Figure 7.7 Nitrogen $\left(\mathrm{NO}_{3}{ }^{-}+\mathrm{NH}_{4}{ }^{+}\right)$concentration in runoff and total inorganic $\mathrm{N}$ concentrations in deposition for 54 European ICP Waters sites in 1990-93, 1996-99, and 2002-05. Deposition data are interpolated from adjacent EMEP stations. The sites include lake and stream sites from 8 European countries ranging from the Mediterranean to Scandinavia (1 mg N/I is equivalent to about 70 Heq/l) (from Kaste et al. 2007). a number of sites with significant increasing trends in nitrate leaching discernible above the 'noise' of temporal variations at various timescales (Figure 7.8), despite static or declining levels of $\mathrm{N}$ deposition. While other drivers (climate, de-acidification) may explain some of these increases, the possibility of a nitrogen saturation signal cannot be ruled out (Butterbach-Bahl et al., 2011, Chapter 6 this volume). As excess sulphate concentrations have fallen in response to declining $\mathrm{S}$ emissions, the importance of $\mathrm{NO}_{3}{ }^{-}$and $\mathrm{NH}_{4}{ }^{+}$in acidification and preventing recovery has increased in relative terms $(\mathrm{N}$ vs. $\mathrm{S})$ and at some sites may continue to increase in absolute terms (Curtis et al., 2005; Rogora and Mosello, 2007).

\subsection{Nitrogen processing in freshwater systems}

Surface freshwaters, including streams, rivers, lakes and other standing waters receive nitrogen both as non-point sources from surface and groundwater runoff from their watershed, and from point sources from direct discharge of treated or untreated urban wastewater. As a rule, nitrate concentrations and fluxes
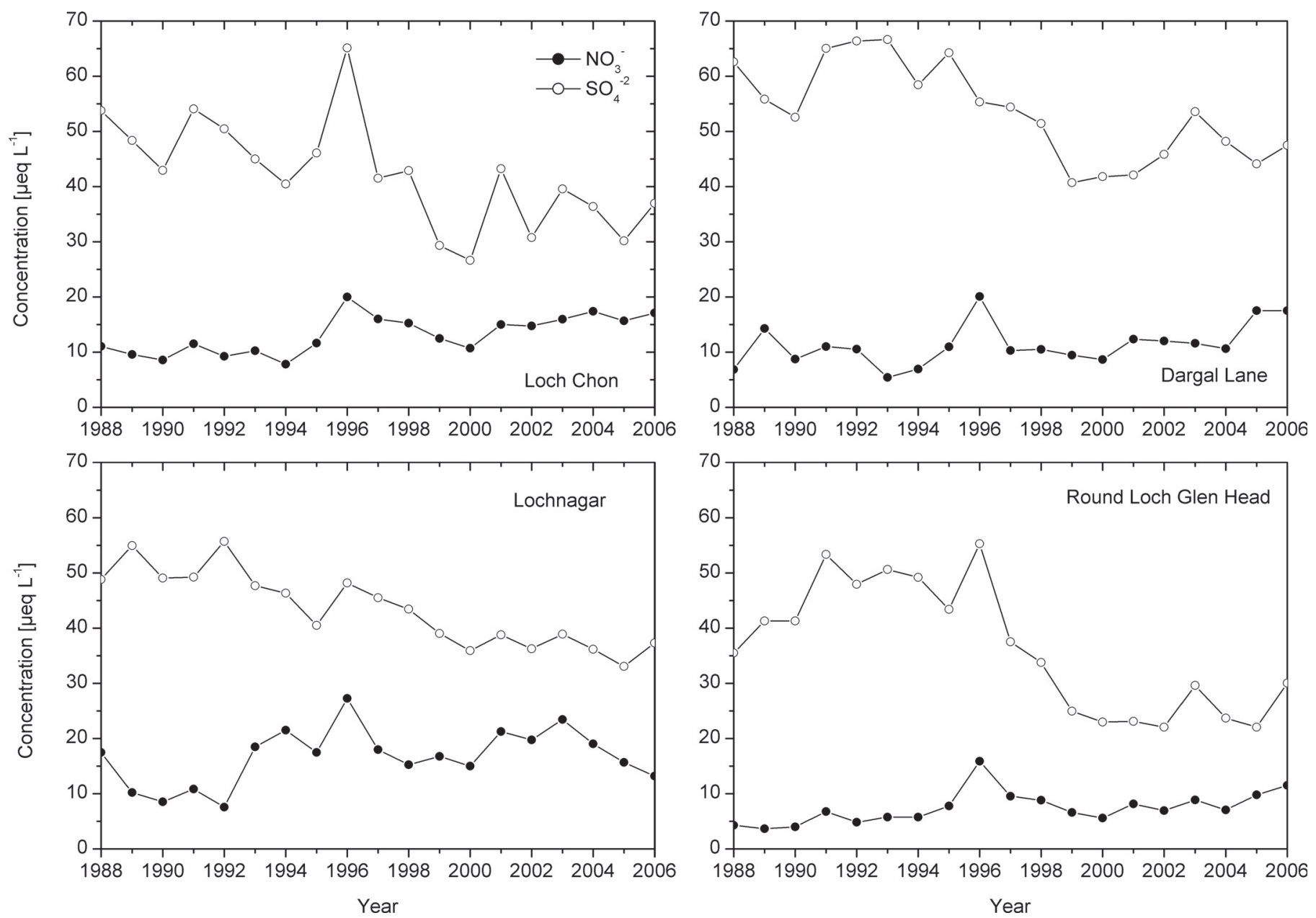

Figure 7.8 Annual mean concentrations of excess (non-marine) sulphate and nitrate in four sites from the UK Acid Waters Monitoring Network. Data for lakes (Lochnagar, Round Loch of Glenhead, Loch Chon) based on quarterly samples, stream (Dargall Lane) monthly samples. 
in rivers are significantly lower than in the soil sources in their catchments. A part of this abatement is explained by the role of riparian wetlands in transforming nitrate to gaseous forms and to organic $\mathrm{N}$ stored in wetland soil porewaters and biomass, en route from catchment to stream. Another part results from in-stream processes leading to transformation of the $\mathrm{N}$ load in transit from headwater streams to estuarine and coastal waters as well as from groundwater to surface water. The following section will discuss the dominant N-relevant processes of the different freshwater systems.

\subsubsection{Groundwater}

Groundwater (saturated) and vadose (unsaturated) zones have four major roles in the $\mathrm{N}$ cycle:

- infiltration and groundwater flow serve to transfer, often with significant time lags, nitrogen from soils to groundwater bodies (aquifers) and in turn to surface-water bodies via groundwater baseflow;

- exchange of water between surface waters and groundwaters takes place through the biogeochemically active hyporheic zone where rapid cycling of $\mathrm{N}_{\mathrm{r}}$ may take place;

- low flow-rates and long travel distances allow these zones to store large quantities of nitrogen, principally as nitrate;

- long residence times and specific biogeochemical conditions may allow nitrogen processing, especially through biotic reduction processes, particularly denitrification.

Groundwater is hence both a receptor of pollution and a pathway to surface water receptors. Although elevated nitrate has been recognised in groundwater since the 1870s (Addiscott, 1996), the seriousness of this occurrence was not fully appreciated until a century later (Foster et al., 1986; Rivett et al., 2007).

\section{Residence times and storage capacity}

Transfer of nitrogen to the subsurface zone (Figure 7.4) may occur via leaching of soils, point-source discharges, particularly via septic tank systems, or river seepage through the hyporheic zone (Dages et al., 2008). Although some discharges, e.g. point sources, may occur in the form of ammonium or DON, nitrification to nitrate is typical in aerated unsaturated zone and shallow groundwater. Nitrate migrates down through the unsaturated zone at a slow rate with nitrate fronts discernable in many systems (Kinniburgh et al., 1999). In many porous or dual-porosity porous-fissured aquifers such as sandstones or chalk-limestones, rates of downward nitrate movement are typically $0.2-1 \mathrm{~m} / \mathrm{yr}$ (Rivett et al., 2007). Hence it may take years to decades for the main nitrate front to reach deep water tables as $10-50 \mathrm{~m}$ thick vadose zones are not uncommon. Even where units are fissured, nitrate diffusion to a porous rock matrix will cause limited flow rates. Below the water table, lateral groundwater flow causes nitrate to spread throughout the aquifer with some flow lines ultimately discharging to receiving surface water bodies and others migrating deeper to aquifer units potentially confined by overlying low permeability units.
Velocities in groundwater are governed by the hydraulic gradient, effective porosity and hydraulic conductivity of units that may vary over orders of magnitude (Martin et al., 2006). Flow rates are typically in the range of $10-100 \mathrm{~m} / \mathrm{yr}$. However, in highly fissured karst systems, rates may reach kilometres per day, with significantly contrasting water ages occurring in the subsurface zone (Boehlke and Denver, 1995).

Storage of nitrate in the subsurface-groundwater zone, thought to be relatively small at the global scale, can locally be a significant part of a catchment nitrogen budget, even in areas underlain with crystalline bedrocks (Durand, 2004; Basset-Mens et al., 2006). Nitrate fronts slowly migrating down through unsaturated zones tens of metres thick and of high porosity (and hence large water storage capacity) is of particular concern. The principal impact on the underlying groundwater and in turn receiving surface waters may occur decades after $\mathrm{N}$ application at surface. Many aquifers used for water supply or replenishment of surface waters are relatively porous $(10 \%-40 \%)$ and where such aquifer thicknesses are large $(+50 \mathrm{~m})$ storage of nitrate may be substantial (Jackson et al., 2007). This is evident for example in aquifers of consolidated sedimentary sandstone or chalk/limestone deposits in some lowland parts of Europe. Water quality improvements arising from any protection zone initiatives taken to reduce nitrogen inputs at surface (Johnson et al., 2007) may hence become apparent years to decades after their implementation (Beaudoin et al., 2005; Jackson et al., 2008).

\section{Transformation processes}

Microbial transformation of nitrate in the subsurface-groundwater zone is hence critical to the reduction of its impacts. Heterotrophic denitrification, with organic $\mathrm{C}$ as an electron donor ultimately forming nitrogen gas, is generally thought to be the dominant attenuation process amongst several other processes (Rivett et al., 2008). The latter include autotrophic denitrification by reduced iron or sulphur, dissimilatory nitrate reduction to ammonium, anoxic oxidation of ammonium (anammox) and abiotic nitrate reduction (Korom, 1992; Burgin and Hamilton 2007). Biogeochemical conditions, for example redox and the presence and type of electron donors, are key to establishing their relative importance. Rivett et al. (2008) conclude that as denitrifying bacteria are essentially ubiquitous in the subsurface zone, even to hundreds of metres depth (Neilsen et al., 2006), the critical limiting factors are electron donor concentration and availability. Variability of other environmental conditions (nitrate concentration, nutrient availability, microbial acclimation, $\mathrm{pH}$, temperature, presence of toxins and other co-contaminants such as pesticides) appear to exert secondary influences on denitrification rates in groundwaters.

Although the number of case studies assessing nitrate migration and attenuation steadily increases (Einsiedl et al., 2005; Barkle et al., 2007; Burgin and Hamilton, 2007; Ruckart et al., 2007; Thayalakumaran et al., 2007; Rivett et al., 2007) the frequency of occurrence of transformation types and their rates remain largely unknown (Korom, 1992; Seitzinger et al., 
2006). These studies illustrate that it is technically challenging to investigate the various denitrification/transformation processes in the field with several lines of supporting evidence or methods typically required to characterise bacterial presence, their activity and specificity, nitrogen species present, electron donors, reaction. Often rates estimated are typically low; however, long residence times in the subsurface may result in even low rates of transformation proving important (Rivett et al., 2007). There is hence a crucial need to further develop methods that reliably quantify aquifer denitrification capacities to allow improved prediction of nitrate fluxes (Green et al., 2008).

The ready availability of oxygen in the unsaturated zone and to a lesser extent in unconfined, outcrop aquifer units may cause denitrification to be effectively being absent or present at only low rates. For example, studies of the dual-porosity Chalk of south-east England (summarized in Rivett et al., 2007) demonstrated only low rates of denitrification. This was ascribed to relatively good contact with the atmosphere via its fissure network and the low level of in-situ electron donors. The potential for aerobic denitrification was, however, recognised with the existence of anaerobic micro-sites occurring within generally aerobic environments. Although low oxygen conditions may be present in the chalk matrix, the fine pore matrix may exclude bacteria $(\sim 1 \mu \mathrm{m})$, causing bacterial activity to be largely restricted to fracture sites where it is difficult to establish anaerobic conditions necessary for denitrification without substantial labile C inputs, typically from a pollution source (Gooddy et al., 2002) or perhaps river infiltration.

\section{Importance of DOC}

The presence of DOC in groundwater, often thought to be the primary electron donor in denitrification, is typically low. For example, a >11 000 sample dataset covering 9 different aquifer types in England and Wales indicated aquifer mean DOC varying from $0.7-1.8 \mathrm{mg} / \mathrm{l}$ with DOC rarely exceeding $5 \mathrm{mg} / \mathrm{l}$. Such a concentration would drive little denitrification. The stochiometry of heterotrophic denitrification indicates that $1 \mathrm{mg} \mathrm{C} / \mathrm{l}$ of DOC may convert $0.93 \mathrm{mg} \mathrm{N} / \mathrm{l}$ of nitrate to $\mathrm{N}_{2}$. The DOC is, however, preferentially oxidised by dissolved oxygen that requires $1 \mathrm{mg}$ DOC-C/l to convert $2.7 \mathrm{mg} \mathrm{O}_{2} / \mathrm{l}$. In air-saturated groundwater $(10 \mathrm{mg} \mathrm{O} / \mathrm{l})$, up to about 3.8 $\mathrm{mg}$ DOC-C/L must therefore be oxidised before denitrification can commence (Rivett et al., 2008). For a fully oxygenated groundwater, this represents a DOC level below which anaerobic conditions may not develop and denitrification does not occur. The greatest concentrations of DOC occur near surface, either where groundwaters are being recharged or water is discharged through riparian zones, organic-rich wetlands or hyporheic zone riverbed sediments (Smith and Lerner, 2008).

The relevance of DOC inputs into aquifers for sustaining heterotrophic denitrification has recently been challenged. Siemens (2003) and Green et al. (2008) report DOC fluxes into a sandy aquifer in northern Germany and a set of four sandy aquifers across the USA, and suggest that these are insufficient to account for oxygen and nitrate consumption. In addition, Green et al. (2008) suggest that literature denitrification rates are biased towards high rates due to (1) a selection bias to aquifers with high denitrification rates, and (2) solely attributing temporal nitrate concentration gradients to denitrification and ignoring the history of $\mathrm{N}$ inputs. Regardless of the actual denitrification rate, the above studies indicate that denitrification in those aquifers relied mainly on the presence of fossil stocks of organic C and reduced sulphur (Kölle et al., 1985). Consumption of organic C, sulphur or ferrous minerals without replenishment increases the risk of a downward oxidation of electron donors and progression of nitrate-rich water further into aquifer units.

In summary, although denitrification rates in groundwater may often be low and difficult to estimate, they are nevertheless important as they may lead to some mitigation of nitrogen pollution delivery to surface waters. The latest global assessment of groundwater denitrification (Seitzinger et al., 2006) gives values ranging from 0 to $7020 \mathrm{~kg} \mathrm{~N} / \mathrm{km}$ per $\mathrm{yr}$, and suggests that European aquifers account for $30 \%$ of the global groundwater denitrification, which is estimated to be $44 \mathrm{Tg} \mathrm{N} / \mathrm{yr}$. This estimate is based on the assumption that heterotrophic denitrification is dominant, and since it is limited by DOC supply from recharge, it is presumed to occur principally in shallower groundwater systems. At present, however, there is insufficient evidence available to support this contention, and this remains an area requiring elucidation through further research.

\subsubsection{Riparian wetlands}

\section{Status, evolution and diversity of freshwater wetlands}

It is believed that at least $50 \%$ of the original area of wetlands has been lost in Europe due to drainage for agriculture and urbanisation. This destruction is still in progress, since almost $4 \%$ of the remaining area has been lost between 1990 and 2000 (Figure 7.9).

Freshwater wetlands comprise a range of very diverse ecosystems. Wetlands dominantly fed by rain water are highly sensitive to atmospheric $\mathrm{N}$ deposition. An associated loss of biodiversity occurs where the rate of $\mathrm{N}$ deposition increases over time, as is the case in many areas of Europe (Dise at al., 2011, Chapter 20 this volume). The other types can, under certain conditions, contribute to removal of inorganic nitrogen from water (see below).

The conversion of riparian wetlands to urban or agricultural use has resulted not only in an increase in size of the potential source of nutrients subject to transfer to the wider environment, but also in the degradation and loss of ecosystems that are capable of reducing or 'buffering' the flux of inorganic $\mathrm{N}$ species from terrestrial to aquatic environments. This nitrate buffering potential of wetlands was first reported in detail in the early 1970s. Subsequently, there have been many publications produced describing the numerous benefits that can be gained from wetlands, often supported by data demonstrating 


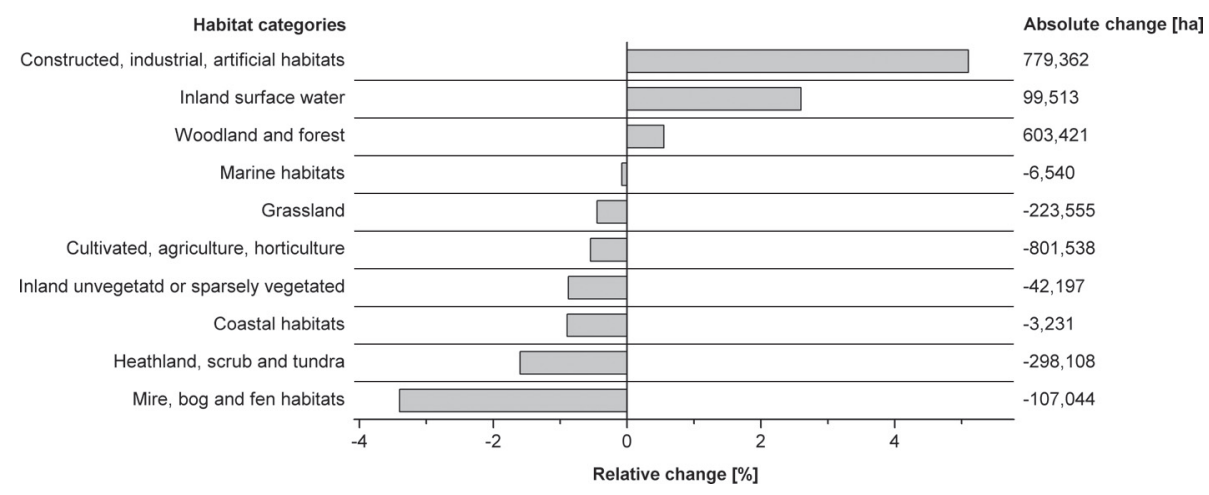

Figure 7.9 Changes in coverage of EUNIS 10 main habitat types from 1990 to 2000 (European Environment Agency, 2005).

their high efficiency in reducing nitrate flux to adjacent surface waters (see Haycock et al., 1997, for a review). This section discusses the potential of freshwater wetlands for regulating water quality by storing and transforming nitrogen through the performance of a variety of physical, chemical and biological functions, and the role of hydrological residence time in controlling this behaviour.

\section{Hydrological linkage between wetlands and the catchment}

There are three main aspects to the hydrology of a wetland that control its ability to transform and store nutrients: (i) the hydrological linkage between the wetland and the wider catchment, (ii) the internal hydrological regime of the wetland and (iii) hydrological pathways within a wetland (McClain et al., 2003).

The location of a wetland in the catchment often is the crucial factor in determining its effectiveness as a zone for nitrogen transformation (Johnston et al., 1990). Historically, the assessment of the impact of riparian wetlands on $\mathrm{N}_{\mathrm{r}}$ flux at the catchment scale has focussed on the total area of wetlands present. However, in wetlands where the main source of water is via diffuse shallow groundwater, it is often the wetland/terrestrial interface that is the active zone in terms of the reduction of nitrate concentrations in inflowing water. The location of nitrate removal at the upslope edge of a riparian buffer zone receiving water from the hillslopes is explained by the combination of high nitrate concentrations in the runoff, high carbon concentrations in the soil (essential as a respiratory substrate for the denitrifying bacteria), and anaerobic conditions resulting from elevated water table. This combination provides optimal conditions for denitrification to occur (Pinay et al., 1989). Nitrate concentrations are sometimes depleted over a few metres within this zone, and the rest of the wetland often shows very low denitrification rates (Sabater et al., 2003). As a consequence, the length of interface between the wetland and upslope sources of nutrient rich runoff is often an important factor determining the impact of the wetland on nitrate reduction.

While the hydrological connectivity between wetlands and sources of nutrients in the catchment controls the degree of contact between inflowing nutrients and wetland biogeochemical cycling processes, the effectiveness of that processing depends on the internal hydrological regime and hydrological pathways of the wetland (Pinay et al., 2002). Wetlands have a wide range of hydrological regimes, and these are influenced by many factors, including soil type, location in the catchment and geomorphology. In soils with low permeability, if the inflow is moderate (upstream locations, baseflow conditions), the residence time of water may be long enough for anoxic conditions to develop, and denitrification may be the dominant process influencing $\mathrm{N}$ concentrations in wetland soil porewaters. If the rate of inflow is higher (e.g. during storm events), this function may be bypassed through flushing of soil porewater stores and generation of preferential and/or overland flow to adjacent surface waters. In this circumstance, $\mathrm{N}$ retention rates and/or denitrification rates will be substantially reduced. In permeable soils, if the inflow is low, oxic conditions may dominate. This is also the case if the rate of inflow is very high because residence time is not long enough for anoxic conditions to develop. In both cases, denitrification is less significant, and plant uptake with subsequent microbial decomposition of plant material leads to the conversion of nitrate to PON and DON. In high flow events, when the water table rises in these systems, lateral flushing of DON-rich water can occur, so that these wetlands do not reduce total $\mathrm{N}$ flux to surface waters, they merely attenuate the rate and $\mathrm{N}$ form of the delivery (Prior and Johnes, 2002). It follows that, in general, the actual efficiency of riparian wetlands to denitrify inflow is much less than has been reported in studies where nitrate concentrations only are considered.

\section{Side effects of nitrate removal by wetlands}

Although the beneficial effects of buffer zones on nitrate flux to surface waters have been widely documented, the complete environmental assessment of increased $\mathrm{N}$ loads in wetlands must include the potential limitations and adverse effects (Haag and Kaupenjohann, 2001). For example, increased $\mathrm{N}_{2} \mathrm{O}$ emission rates due to higher $\mathrm{N}$ availability and denitrification favouring conditions are likely. Factors such as acidic conditions and low temperatures further alter the $\mathrm{N}_{2} \mathrm{O} / \mathrm{N}_{2}$ ratio in the denitrification process. Increased $\mathrm{CO}_{2}$ emissions are likely as well, due to increased organic matter oxidation in these systems. Another side effect is the release of DOC and DON into the streams, as mentioned above. Finally, increased $\mathrm{N}$ load can damage the ecological status of the wetland. This is obvious in the case of oligotrophic wetlands, but it is also the case for 
mesotrophic wetland ecosystems, leading to reduced biodiversity and altered structure and function in the wetland ecosystem. In addition, as the wetland nutrient store reaches capacity, the nitrogen storage and attenuation function of these wetlands will be compromised.

\subsubsection{Running waters}

\section{$\mathrm{N}$ cycling and transformation}

$\mathrm{N}$ cycling and transformations in river systems occur in the sediment and in the water column and are mainly controlled by the hydrological conditions (Figure 7.10).

Organic matter decomposition and ammonium release by heterotrophic activity in rivers is mainly controlled by the input of organic material either from primary production or from allochthonous origins (litter fall, wastewater release and transfer from upstream). Typical values of bacterial production rate measured in the water column of European rivers ranges between $0.005-0.05 \mathrm{mg} \mathrm{C} / 1$ per day for uncontaminated forest streams, between $0.01-0.5 \mathrm{mg} \mathrm{C} / 1$ per day for large rivers, and can reach $2.5 \mathrm{mg} \mathrm{C} / 1$ per day in rivers heavily contaminated with urban sewage (Billen et al., 1995). Taking into account a $\mathrm{C} / \mathrm{N}$ ratio of 6-7 for the organic material serving as substrate, and a growth yield of 0.5 , these productions rates correspond roughly to an in-stream release of ammonium of 0.001-0.01 $\mathrm{mg} \mathrm{N} / \mathrm{l}$ per day, $0.02-0.1 \mathrm{mg} \mathrm{N} / \mathrm{l}$ per day and $0.5 \mathrm{mg} \mathrm{N} / \mathrm{l}$ per day respectively.

Nitrification occurs in rivers where large amounts of ammonium are present, most often because of untreated urban wastewater release, and can lead to severe oxygen depletion (Chestérikoff et al., 1992). Nitrification rates as high as $0.1 \mathrm{mg} \mathrm{N} / \mathrm{l}$ per day have been recorded in European rivers (Brion and Billen, 2000). Seeding of river water by nitrifying bacteria occurs through soil erosion but also by sewage release (Brion and Billen, 2000; Cebron et al., 2004; Cebron et al., 2005). Under low oxygen concentration $\left(<2 \mathrm{mg} \mathrm{O}_{2} / \mathrm{l}\right)$, ammonium oxidising bacteria are able to make use of nitrite as an alternative electron acceptor. The process, called nitrifying denitrification, leads to the production of large amounts of $\mathrm{N}_{2} \mathrm{O}$ (Tallec et al., 2006; Garnier et al., 2007).

Denitrification occurs in the water column of river systems only when the oxygen concentration has dropped below a threshold of about $1 \mathrm{mg} \mathrm{O} / \mathrm{L}$. There exist a number of well documented situations where this happened and resulted in the complete removal of the river nitrate load (Chestérikoff et al., 1992). Fortunately, the progress of wastewater treatment which was primarily aimed at reducing the organic matter loading and improving the oxygen status of surface water has now resulted in the disappearance of these situations of severe oxygen depletion in most major European rivers. However, denitrification, which occurs in sediments, can be responsible for an important flux of nitrate from the water column (Figure 7.11). The role of periphytonic biofilms in denitrification has been highlighted in many studies, particularly in rivers without any significant deposit of fine sediments, and where significant hyporheic flow occurs through pebble, gravel or sand beds (Boulton et al., 1998; Claret et al., 1998; Mermillod-Blondin et al., 2005; Revsbech et al., 2005).

River primary production and inorganic nitrogen uptake. In streams, effects of eutrophication on primary producers are less visible than in standing waters. Hydraulic flushing prevents algal blooms in these systems and hydraulic drag restricts vertical growth of macrophytes (Biggs, 1996; Hilton et al., 2006). Additionally, limitation by light can be important if the sediment load of a stream is high or if the stream is shaded by riparian forest. Nevertheless, there is much evidence

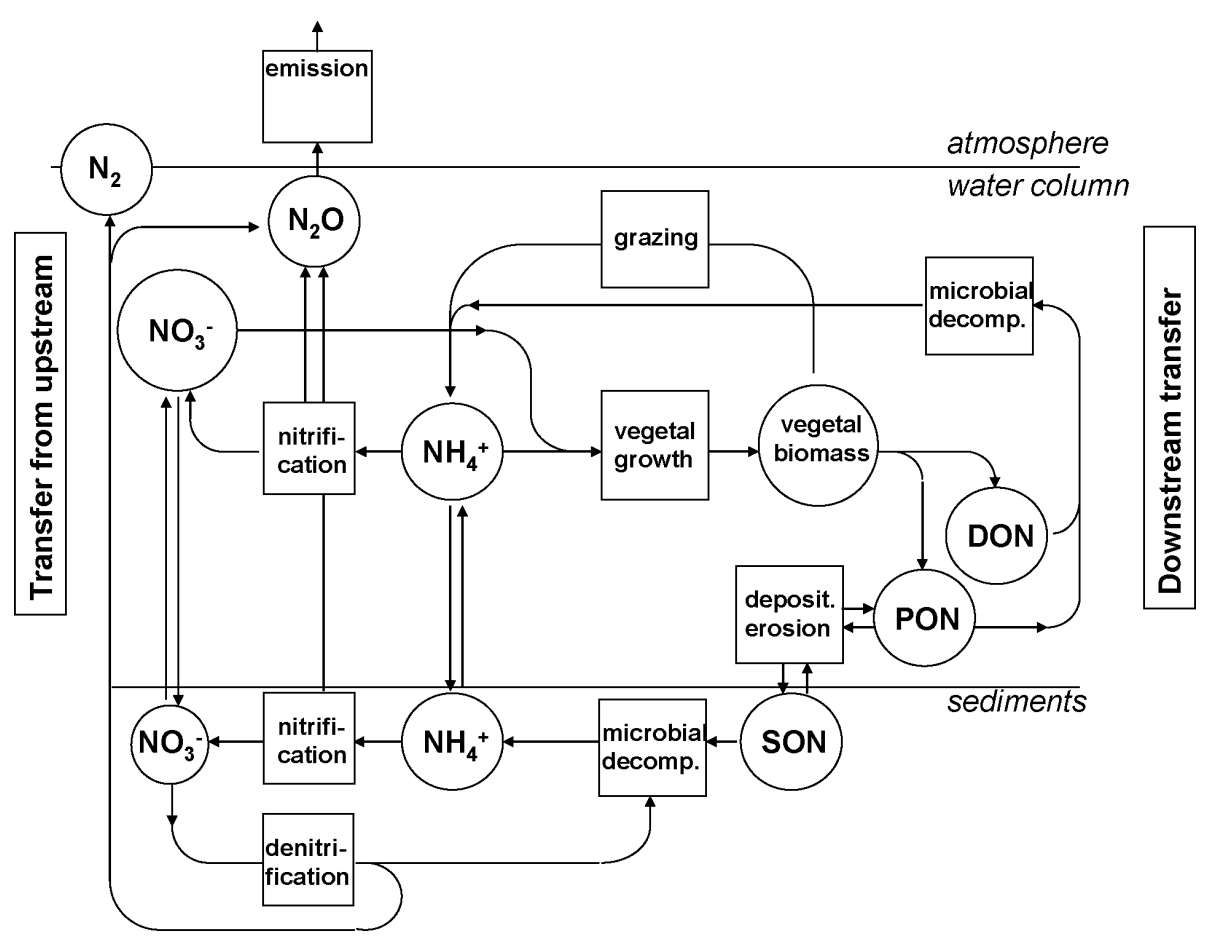

Figure 7.10 The nitrogen spiralling in river systems: a general scheme of the processes affecting nitrogen species during their downstream transfer in rivers. 


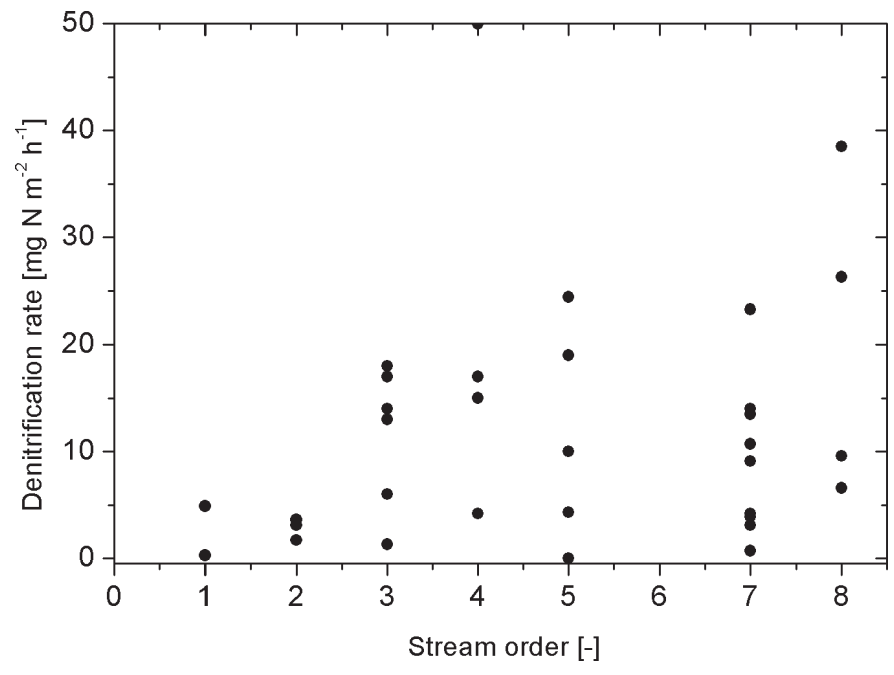

Figure 7.11 Benthic denitrification rates measured with belljars or benthic chambers in European rivers of different stream order (data from Billen et al., 1985; Chestérikoff et al., 1992; Garban et al., 1995; Sanchez, 1996; Thouvenot et al. 2007; Billen et al., 2007; de Klein, 2008).

showing that both $\mathrm{N}$ and $\mathrm{P}$ affect periphyton and phytobenthos growth in streams (Elser et al., 2007) with dense development of filamentous and/or epiphytic algae characteristic of highly eutrophicated rapidly flowing rivers. Uptake by algae or macrophytes is the main mechanism by which $\mathrm{N}_{\mathrm{r}}$ can be transformed into organic particulate (or dissolved) form. Low molecular weight DON can also be taken up directly by plants, and can represent an important pathway to support production in higher plant and algal communities in $\mathrm{N}$ limited waters from lakes to estuaries and coastal waters (Antia et al., 1991; Seitzinger and Sanders, 1997).

\section{In-stream nitrogen retention}

Empirical measurement of nitrogen in-stream retention capacity has been carried out in small experimental streams under steady discharge conditions. In brief, the experiments increase the background concentration of a nutrient in stream water and monitor its downstream spatial and temporal decay (Ensign and Doyle, 2006). The results show a high variability of retention capacity, the broad picture being that this is higher for ammonium than for nitrate and much higher in pristine sites than in N-enriched sites (Marti et al., 2004).

On the scale of catchments and individual waterbodies nitrogen removal can be estimated from balancing incoming $\left(\mathrm{N}_{\text {in }}\right)$ and outflowing $\left(\mathrm{N}_{\text {out }}\right)$ fluxes. The retention fraction (\%) is thus defined as $100 *\left(1-N_{o u} t / N_{i n}\right)$. For whole system $\mathrm{N}$ retention the average hydraulic residence time is a major controlling factor (Nixon et al., 1996; Seitzinger et al., 2002).

Kelly et al. (1987) proposed a model of nitrogen removal through benthic denitrification in lakes and Howarth et al. (1996) extended this approach to river reaches. The model relates nitrogen loss through denitrification to water residence time $(\tau)$, mean water column depth $(z)$, and an average mass transfer coefficient $\mathrm{Sn}(\mathrm{m} / \mathrm{yr})$ which can be approximated by the ratio between mean areal denitrification rate and mean

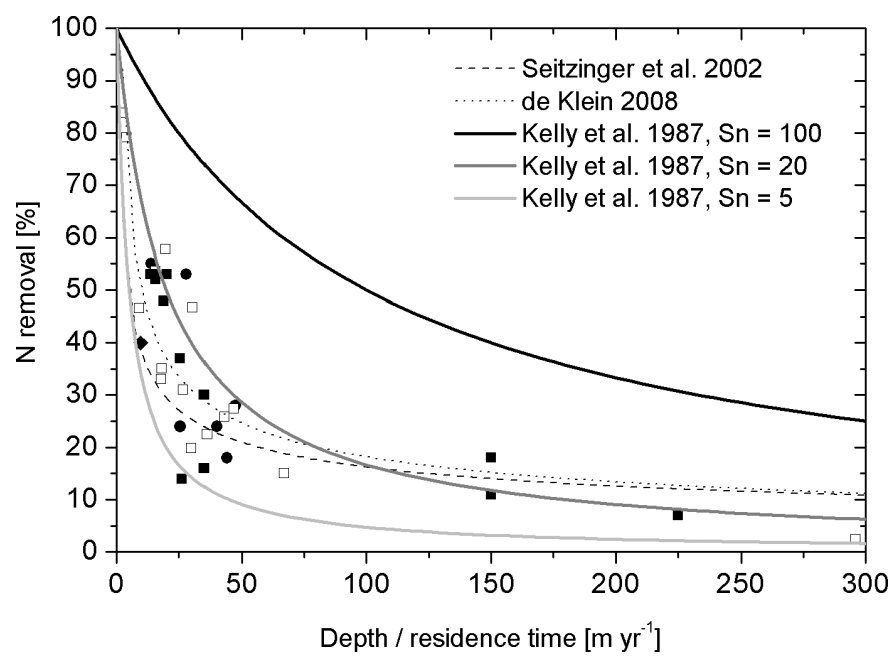

Figure 7.12 Percent $N$ removal $\left(100^{*}\left(1-\right.\right.$ total $\left.N_{\text {out }} / N_{\text {in }}\right)$ vs. water column depth to residence time ratio in a number of European lakes and rivers stretches. Data include Italian lakes ( $)$; Danish lakes ( $($ ) (Andersen, 1977), Seine Reservoirs ( $\square$ ) (Garnier et al., 1999) and a number of river stretches ( $\square$ ) (Cooke and White, 1987; Christensen and Sorensen, 1988; Chestérikoff et al., 1992; de Klein, 2008). Solid lines result from the application of Kelly's model (with Sn respectively 100, 20 and $5 \mathrm{~m} / \mathrm{yr}$ ). The dashed line is the empirical formula proposed by Seitzinger et al. (2002), the dotted line is the formula proposed by de Klein (2008).

nitrate concentration in the water column, if first order denitrification kinetics is assumed

$$
\% \mathrm{~N}_{\text {removed }}=100^{*} \mathrm{Sn} /(\mathrm{z} / \tau+\mathrm{Sn})
$$

The ratio $z / \tau$ is referred to as water displacement (Seitzinger et al., 2002); Sn is typically in the range of $5-100 \mathrm{~m} / \mathrm{yr}$ in Western European rivers. Figure 7.12 shows that this model fits reasonably well the empirical estimates obtained for a number of European lakes and river reaches. Seitzinger et al. (2002) proposed an alternate empirical expression of relation (Eq. (7.1)) which fits both river and lake observations:

$$
\% \mathrm{~N}_{\text {removed }}=88.45(\mathrm{z} / \tau)^{-0.37} \text {. }
$$

De Klein (2008) obtained a very similar relationship based on the nitrogen budget of a number of lowland ditches and river systems:

$$
\% \mathrm{~N}_{\text {removed }}=138(\mathrm{z} / \tau)^{-0.44} \text {. }
$$

They also stressed that, although the proportion of $\mathrm{N}$ inputs that is removed in an individual river stretch is generally low $(<20 \%$, see Figure 7.11$)$, the cumulative effect of continued $\mathrm{N}$ removal along the entire flow path of a drainage network can result in much higher overall $\mathrm{N}$ removal.

\subsubsection{Standing waters}

\section{N processing in standing waters and major controlling factors}

In lakes, $\mathrm{N}_{\mathrm{r}}$ can come from direct atmospheric inputs in the form of wet and dry deposition, and $\mathrm{N}_{2}$ fixed by cyanobacteria. These inputs may be more significant in lakes, compared to rivers, given the greater surface area for exchange to take place. In lakes, $\mathrm{N}$ is also derived from influx of both inorganic and organic $\mathrm{N}$ from catchment sources delivered by surface and subsurface flow pathways and in some geological environments, 
predominantly from groundwater stores. Internal loading derives from the microbial decomposition of $\mathrm{N}$ stored in aquatic plant and algal biomass and in lake sediment stores.

Turnover of $\mathrm{N}$ in standing waters is controlled by the population dynamics of pelagic (open water), littoral (shoreline) and benthic (bottom dwelling) organisms, with the relative significance of these different groups varying among lake types. For example, in shallow lakes with a high littoral (shallow water) to profundal (deep water) ratio, $\mathrm{N}$ turnover is dominated by inorganic and organic $\mathrm{N}$ uptake by aquatic plants and organic $\mathrm{N}$ decomposition by the microbial community. In deeper lakes, with a low littoral to profundal ratio the free-floating planktonic community will be dominant and exert substantial control over $\mathrm{N}$ turnover in the lake. The balance of control is also influenced by water transparency (controlling the depth of light penetration), macro-nutrient availability ( $\mathrm{N}$, $\mathrm{P}$ and $\mathrm{C}$, derived from external sources, internal stores and sediment-water column interactions), the vertical mixing regime (depending on currents, depth and climate), and the residence time for water entering the lake which determines the length of contact time between $\mathrm{N}$ entering the lake and the lake biota. The mixing regime in particular is a specific feature of standing waters as well as large, slow rivers: while the typical pattern of temperate lakes is a dimictic regime with a winter stratification (cooler water at surface) and a summer one (cooler water at the bottom), some lakes are monomictic (stratified only in summer), polymictic (many mixes, e.g. shallow lakes and ponds), or meromictic (never fully mixed because of a stagnant bottom layer). These regimes affect the sensitivity of water bodies to eutrophication and the nitrogen cycling dynamics: for example, in poorly mixed hypertrophic lakes, the hypolimnion (bottom layer including the sedimentwater interface) may become anoxic, so denitrification and ammonium accumulation are promoted.

\section{Nitrogen loadings in European lakes and the question of $\mathrm{N}$ versus $\mathrm{P}$ limitation}

The $\mathrm{N}$ concentrations in lakes vary widely, depending on the relative rates of atmospheric $\mathrm{N}$ deposition, and the intensity of human perturbation of land in the surrounding catchment; $\mathrm{N}$ relative to $\mathrm{P}$ loading is also highly variable, depending on the relative contribution of atmospheric and diffuse nutrient delivery from atmospheric and terrestrial sources ( $\mathrm{N}$ rich) and point source (particularly sewage treatment works, P rich) (Johnes, 2007b). Data collated by the International Lake Environment Committee contains information on 40 European lakes (Figure 7.13), including records for varying time periods for 16 large European lakes for which total $\mathrm{N}$ and $\mathrm{P}$ loading rates are reported (Table 7.1). Annual loads to the catchment vary from $<0.02 \mathrm{~kg} \mathrm{~N} /$ ha for Bodensee to $29 \mathrm{~kg} \mathrm{~N} /$ ha for Lake Paajarvi in Finland. Of these, $25 \%$ of lakes were reported as $\mathrm{N}$ limited or $\mathrm{N}$ and $\mathrm{P}$ co-limited, compared to over $75 \% \mathrm{P}$ limited lakes.

The question of $\mathrm{N}$ vs. $\mathrm{P}$ limitation in lakes has been largely debated in the literature, and what emerges from this debate is a more complex picture than the common idea that $\mathrm{P}$ is the cause of eutrophication in freshwaters. Although it is true that $\mathrm{P}$ limitation is most commonly reported, $\mathrm{N}$ and $\mathrm{P}$ co-limitation and $\mathrm{N}$ limitation are not rare, at least periodically, and may well occur in many European standing water bodies (Moss et al., 1996; Maberly et al., 2002; James et al., 2003). In cases of $N$ and $\mathrm{P}$ enrichment, silica may be also limiting after diatom growth, giving way to possibly undesirable non-diatoms (Schelske and Stoermer 1971). Note that N limitation or co-limitation can occur in different contexts.

- Exceptionally P rich lakes, and lakes with very low N loads. In both cases, this may result in production by both the phytoplankton community in the open water areas, and the macrophyte community rooted in $\mathrm{P}$ rich sediment being limited by $\mathrm{N}$ rather than $\mathrm{P}$ availability.

- Shallow, well mixed water bodies: since the main store of $\mathrm{P}$ is in sediments, it is more readily available in shallow lakes and internal loading of $P$ from these stores makes a substantial contribution to $\mathrm{P}$ availability in the open water areas. The diffusion to upper layers in deep, stratified lakes is much slower, typically resulting in $\mathrm{P}$ limitation of primarily phytoplankton production in the euphotic zone (where primary production is not limited by light availability).

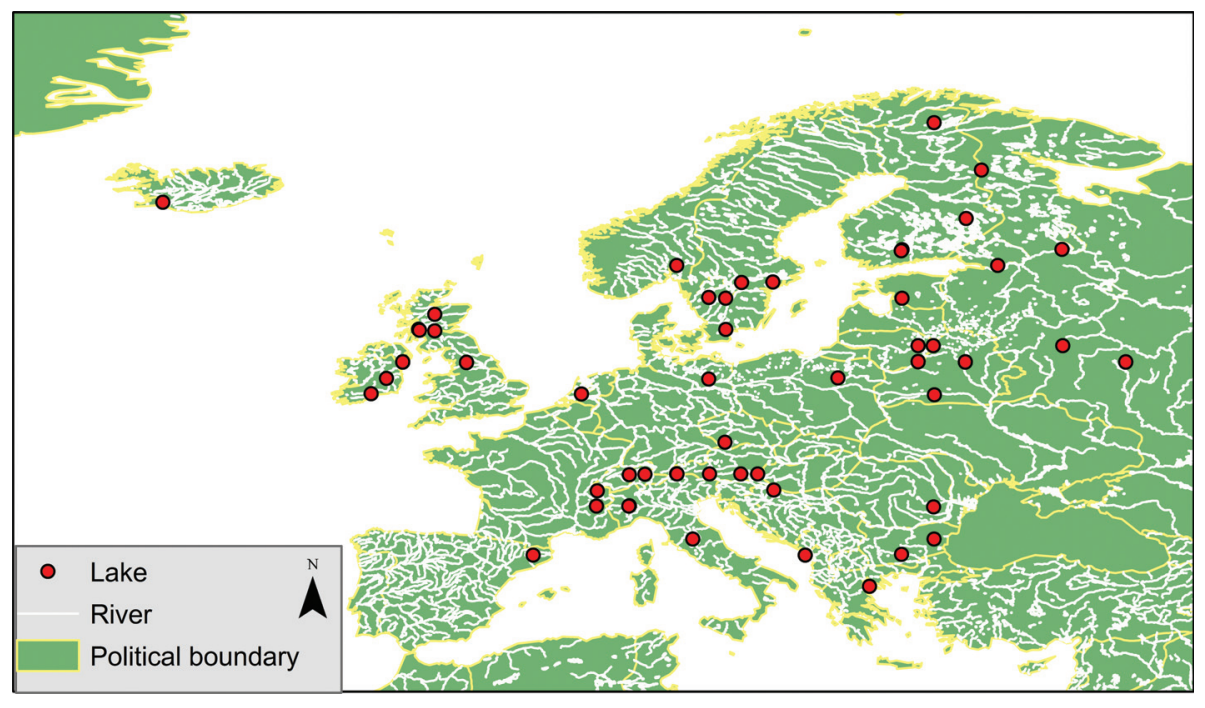


Table 7.1 Reported TN and TP loadings for large European lakes (International Committee Lake Foundation, 2010)

\begin{tabular}{|c|c|c|c|c|c|c|}
\hline Lake & Country & $\begin{array}{l}\text { Catchment } \\
\text { area }\left(\mathrm{km}^{2}\right)\end{array}$ & $\begin{array}{l}\text { TN loading } \\
(\mathrm{t} / \mathrm{yr})\end{array}$ & $\begin{array}{l}\text { TP loading } \\
\text { (t/yr) }\end{array}$ & $\mathrm{N}: \mathrm{P}$ ratio & N or P limited \\
\hline Lake Constanz & Germany & 10900 & 21.0 & 2.3 & 9.13 & co-limited \\
\hline Lake Slapy & Czech & 12900 & 18200 & 247 & 73.7 & P \\
\hline Lac d'Annecy & France & 278 & 550 & 39.3 & 14.0 & $P$ \\
\hline Lough Derg & Ireland & 10280 & 6245 & 215 & 29.1 & P \\
\hline Lac Leman & France & 7975 & 1300 & 1350 & 0.96 & $\mathrm{~N}$ \\
\hline Lake Balaton & Hungary & 5181 & 3484 & 314 & 10.0 & co-limited \\
\hline Lago Maggiori & Italy & 6387 & 11000 & 550 & 20.0 & P \\
\hline Lago Trasimeno & Italy & 396 & 433 & 422 & 10.3 & co-limited \\
\hline Lake Tyrifjordan & Norway & 9808 & 1600 & 70.0 & 22.9 & Co-limited \\
\hline Lake Mjosa & Norway & 16567 & 4430 & 257 & 17.2 & $P$ \\
\hline Lake Hjalmaren & Sweden & 3575 & 2750 & 65.0 & 42.3 & P \\
\hline Lake Malaren & Sweden & 21640 & 13400 & 590 & 22.7 & P \\
\hline Lake Vanem & Sweden & 41182 & 17380 & 880 & 19.8 & $P$ \\
\hline Lake Vattern & Sweden & 4530 & 3370 & 65.0 & 51.9 & $P$ \\
\hline Lake Paajarvi & Finland & 2550 & 74.3 & 22.5 & 30.3 & $P$ \\
\hline Lake Paijanne & Finland & 25400 & 5475 & 183 & 30.0 & $P$ \\
\hline Lake Pielinen & Finland & 12823 & 2600 & 114 & 22.8 & $P$ \\
\hline
\end{tabular}

- Summer N limitation in eutrophic lakes where the earlier algal blooms have exhausted the dissolved $\mathrm{N}$ in the water column, and delivery from diffuse catchment sources is at its annual minimum.

- Lakes in either Mediterranean or Nordic environments, where both $\mathrm{N}$ and $\mathrm{P}$ loadings (mainly atmospheric) are very low (Camacho et al., 2003; Rekolainen et al., 2004; Bergstroem and Jansson, 2006).

While most of the studies have focused on limitation of phytoplankton production, similar results have been found for periphyton (Maberly et al., 2002) and for the macrophyte community (James et al., 2005).

A representative example of these findings is the recent paper by Phillips et al. (2008) who studied the relationship between growing season chlorophyll $a$ (as a function of phytoplankton production), total $\mathrm{P}$ and total $\mathrm{N}$ concentrations in over 1000 European lakes under the EU REBECCA programme (Figure 7.14). The database was dominated by lakes from north and central Europe, but a number of Mediterranean sites were also included. Phillips and colleagues concluded that growing season chlorophyll $a$ concentrations were significantly related to both TN and TP and that although TP was the best descriptor of growing season chlorophyll $a$ for the whole lake database, TN was a better predictor than TP for humic high alkalinity and very shallow polyhumic lakes, suggesting $\mathrm{N}$ limitation of phytoplankton productivity in the growing season in these lake types.

High $\mathrm{N}$ loads have also been reported to be responsible for loss of biodiversity, especially for submerged plants. In a range of UK and Polish lakes the richest submerged plant communities were associated with winter nitrate concentrations not exceeding $2 \mathrm{mg} \mathrm{N} / \mathrm{l}$ (James et al., 2005) and the authors propose this as an appropriate target concentration for enriched shallow European lakes to reach 'good ecological status' under the EU Water Framework Directive. Many shallow north temperate European lakes have concentrations well in excess of this limit. Van der Molen et al. (1998) for example, reported that $65 \%$ of over 200 Dutch lakes had a summer mean total $\mathrm{N}$ concentration higher than $2.2 \mathrm{mg} \mathrm{N} / \mathrm{l}$. They argue that an appropriate target to protect against ecological deterioration and support recovery of eutrophic lakes is a summer mean concentration of $1.35 \mathrm{mg} \mathrm{N} / \mathrm{l}$. In only $30 \%$ of lakes studied by Moss et al. (1996) was mean summer total N concentration below this target figure.

It is clear that reduction of both $\mathrm{N}$ and $\mathrm{P}$ is required in shallow eutrophicated waters if both gross productivity is to be reduced and a stable, diverse submerged plant community is to be restored (James et al., 2005). Jeppesen et al. (2005) concluded that to improve the ecological status of shallow lakes it may be necessary to control both $\mathrm{P}$ and $\mathrm{N}$ loading rates. They reported that where external $\mathrm{N}$ loading has been reduced to the lakes in their study, the response time in terms of lake total $\mathrm{N}$ concentrations is relatively short $(<5$ years $)$ compared to the response time for lake total $\mathrm{P}$ concentrations in relation to external P loading (10-15 years). Jeppesen and colleagues attributed these differences to the relative importance of the sedimentary $\mathrm{P}$ store to the lake $\mathrm{P}$ budget. These results also suggest that management of freshwaters needs to take a more holistic view of nutrient control than just relying on controlling the supply of $\mathrm{P}$. 

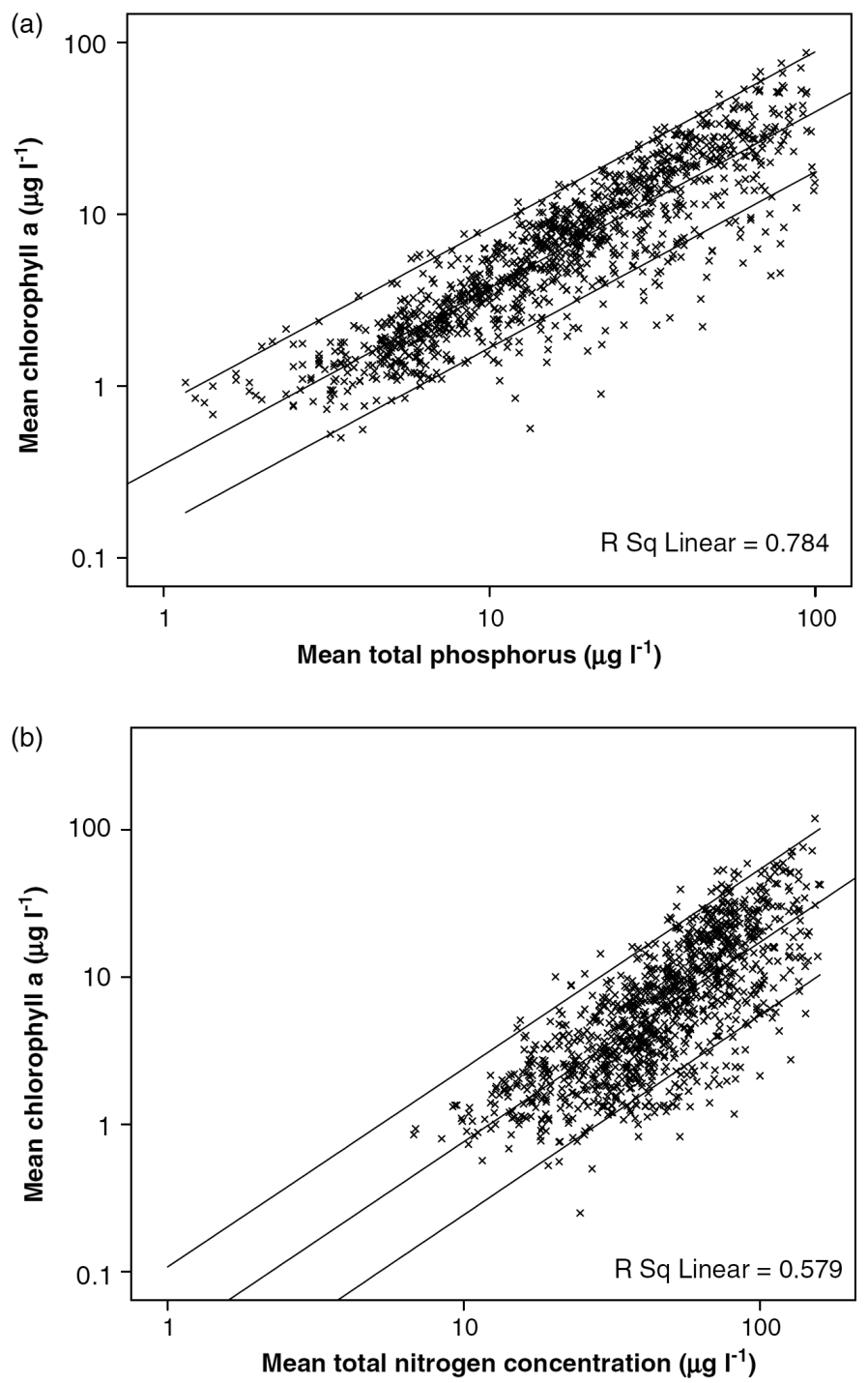

Figure 7.14 Relationship between growing season chlorophyll a, total P and total N concentrations in over 1000 European lakes (Phillips et al., 2008).

\subsection{Conclusions}

Nitrogen enrichment of freshwaters has been taking place throughout Europe, from the advent of modern society, but particularly in the latter half of the twentieth century, where the increasing intensity of agricultural production together with increased industrial and traffic-associated emissions as well as changes in societal management of water and wastewater have led to increased inputs of all plant nutrients to freshwater systems. This enrichment has led to alteration of a wide range of aquatic ecosystem functions including the productivity of water bodies and their microbial metabolism, the microbial, plant and animal community species composition and their relative abundance, and the structure and balance of the aquatic food web.

In terms of ecosystem function, there are relatively few European freshwaters where this has not been altered as a result of $\mathrm{N}$ enrichment, either from land-based or atmospheric sources, posing a problem in terms of achieving compliance with the EU Water Framework Directive (2000/60/EC) as it applies to surface freshwaters, and the EU Groundwater Directive (2006/118/EC) designed to ensure protection of groundwater and groundwater-dependent wetlands against pollution and deterioration in terms of both quantity and chemical quality. The enrichment of European freshwater systems through increases in nitrogen export has compromised a wide range of ecosystem structures, functioning and services and will need to be brought under control through coordinated measures. Consideration will need to be given to a much wider range of sources, practices, and pathways for $\mathrm{N}$ delivery to waters and of the total $\mathrm{N}$ load delivered and transported to waters not merely the inorganic $\mathrm{N}$ fraction if the problem is to be fully addressed. Investigating all effects and managing the cascade of aquatic nitrogen on ecosystem services has not been conducted yet in a comprehensive way and there is a clear need for further research in this respect.

\section{Acknowledgements}

This chapter was prepared with the support of the NinE Programme of the European Science Foundation, the NitroEurope IP (funded by the European Commission) and the COST Action 729.

\section{Supplementary materials}

Supplementary materials (as referenced in the chapter) are available online through both Cambridge University Press: www. cambridge.org/ena and the Nitrogen in Europe website: www. nine-esf.org/ena.

\section{References}

Addiscott, T. M. (1996). Fertilizers and nitrate leaching. In Issues in Environmental Science and Technology 5, ed. R. E. Hester, and R. M. Harrison, Cambridge: The Royal Society of Chemistry, pp. 1-26.

Allott, T. E. H., Curtis, C. J., Hall, J., Harriman, R. and Battarbee, R. W. (1995). The impact of nitrogen deposition on upland surface waters in Great Britain: a regional assessment of nitrate leaching. Water, Air, \& Soil Pollution, 85, 297-302.

Andersen, J. M. (1977). Rates of denitrification of undisturbed sediment from six lakes as a function of nitrate concentration, oxygen and temperature. Archiv für Hydrobiologie, 80, 147-149.

Anderson, M. R. and Kalff, J. (1986). Nutrient limitation of Myriophyllum spicatum growth in situ. Freshwater Biology, 16, 735-743.

Antia, N. J., Harrison, P. J. and Oliveira, L. (1991). Phycological reviews 2: The role of dissolved organic nitrogen in phytoplankton nutrition, cell biology and ecology. Phycologia, 30, 1-89.

Barkle, G., Clough, T. and Stenger, R. (2007). Denitrification capacity in the vadose zone at three sites in the Lake Taupo catchment, New Zealand. Australian Journal of Soil Research, 45, 91-99.

Barko, J. W., Gunnison, D. and Carpenter, S. R. (1991). Sediment interactions with submersed macrophyte growth and community dynamics. Aquatic Botany, 41, 41-65.

Barko, J. W., Smart, R. M., McFarland, D. G. and Chen, R. L. (1988). Interrelationships between the growth of Hydrilla verticillata (L. f.) Royle and sediment nutrient availability. Aquatic Botany, 32, 205-216.

Basset-Mens, C., Anibar, L., Durand, P. and van der Werf, H. M. G. (2006). Spatialised fate factors for nitrate in catchments: modelling 
approach and implication for LCA results. Science of the Total Environment, 367, 367-382.

Beaudoin, N., Saad, J. K., Van Laethem, C. et al. (2005). Nitrate leaching in intensive agriculture in Northern France: effect of farming practices, soils and crop rotations. Agriculture, Ecosystems \& Environment, 111, 292-310.

Beaulieu, J. J., Arango, C. P., Hamilton, S. K. and Tank, J. L. (2008). The production and emission of nitrous oxide from headwater streams in the Midwestern United States. Global Change Biology, 14, 878-894.

Bergstroem, A. K. and Jansson, M. (2006). Atmospheric nitrogen deposition has caused nitrogen enrichment and eutrophication of lakes in the northern hemisphere. Global Change Biology, 12, 635-643.

Bernal, S., Butturini, A. and Sabater, F. (2006). Inferring nitrate sources through end member mixing analysis in an intermittent Mediterranean stream. Biogeochemistry, 81, 269-289.

Biggs, B. J. F. (1996). Hydraulic habitat of plants in streams. Regulated Rivers-Research \& Management, 12, 131-144.

Billen, G., Silvestre, M., Grizzetti, B. et al. (2011). Nitrogen flows from European watersheds to coastal marine waters. In: The European Nitrogen Assessment, ed. M. A. Sutton, C. M. Howard, J. W. Erisman et al., Cambridge University Press.

Billen, G., Décamps, H., Garnier, J. et al. (1995). Atlantic river systems of Europe. Ecosystems of the world, 22, 389-418.

Billen, G., Garnier, J., Némery, J. et al. (2007). A long-term view of nutrient transfers through the Seine river continuum. Science of the Total Environment, 375, 80-97.

Billen, G., Somville, M., DeBecker, E. and Servais, P. (1985). Nitrogen budget of the Scheldt hydrographical basin. Netherlands Journal of Sea Research, 19, 223-230.

Billen, G., Silvestre, M., Grizzetti, B. et al. (2011). Nitrogen flows from European watersheds to coastal marine waters. In: The European Nitrogen Assessment, ed. M. A. Sutton, C. M. Howard, J. W. Erisman et al., Cambridge University Press.

Blicher-Mathiesen, G. and Hoffmann, C. C. (1999). Denitrification as a sink for dissolved nitrous oxide in a freshwater riparian fen. Journal of Environmental Quality, 28, 257-262.

Boehlke, J. K. and Denver, J. M. (1995). Combined use of groundwater dating, chemical, and isotopic analyses to resolve the history and fate of nitrate contamination in two agricultural watersheds, Atlantic Coastal Plain, Maryland. Water Resources Research, 31, 2319-2339.

Boulton, A. J., Findlay, S., Marmonier, P., Stanley, E. H. and Valett, H. M. (1998). The functional significance of the hyporheic zone in streams and rivers. Annual Reviews in Ecology and Systematics, 29, 59-81.

Bouwman, A. F., Drecht, G. and Hoek, K. W. (2005). Surface N balances and reactive $\mathrm{N}$ loss to the environment from global intensive agricultural production systems for the period 1970-2030. Pedosphere, 15, 137-155.

Brion, N. and Billen, G. (2000). Wastewater as a source of nitrifying bacteria in river systems: the case of the River Seine downstream from Paris. Water Research, 34, 3213-3221.

Brown, D. J. A. (1988). Effect of atmospheric $\mathrm{N}$ deposition on surface water chemistry and the implications for fisheries. Environmental Pollution, 54, 275-284.

Burgin, A. J. and Hamilton, S. K. (2007). Have we overemphasized the role of denitrification in aquatic ecosystems? A review of nitrate removal pathways. Frontiers in Ecology and the Environment, 5, $89-96$.

Butterbach-Bahl, K., Gundersen, P., Ambus, P. et al. (2011). Nitrogen processes in terrestrial ecosystems. In: The European Nitrogen
Assessment, ed. M. A. Sutton, C. M. Howard, J. W. Erisman et al., Cambridge University Press.

Camacho, A., Wurtsbaugh, W. A., Miracle, M. R., Armengol, X. and Vicente, E. (2003). Nitrogen limitation of phytoplankton in a Spanish karst lake with a deep chlorophyll maximum: a nutrient enrichment bioassay approach. Journal of Plankton Research, 25, 397.

Cebron, A., Coci, M., Garnier, J. and Laanbroek, H. J. (2004). Denaturing gradient gel electrophoretic analysis of ammoniaoxidizing bacterial community structure in the lower Seine River: impact of Paris wastewater effluents. Applied and Environmental Microbiology, 70, 6726.

Cebron, A., Garnier, J. and Billen, G. (2005). Nitrous oxide production and nitrification kinetics by natural bacterial communities of the lower Seine river (France). Aquatic Microbial Ecology, 41, 25-38.

Chapin, F. S., III, Moilanen, L. and Kielland, K. (1993). Preferential use of organic nitrogen for growth by a nonmycorrhizal arctic sedge. Nature, 361, 150-153.

Chestérikoff, A., Garban, B., Billen, G. and Poulin, M. (1992). Inorganic nitrogen dynamics in the river Seine downstream from Paris (France). Biogeochemistry, 17, 147-164.

Christensen, P. B. and Sorensen, J. (1988). Denitrification in sediment of lowland streams: Regional and seasonal variation in Gelbaek and Rabis Baek, Denmark. FEMS Microbiology Letters, 53, 335-344.

Claret, C., Marmonier, P. and Bravard, J. P. (1998). Seasonal dynamics of nutrient and biofilm in interstitial habitats of two contrasting riffles in a regulated large river. Aquatic Sciences-Research Across Boundaries, 60, 33-55.

Clough, T. J., Bertram, J. E., Sherlock, R. R., Leonard, R. L. and Nowicki, B. L. (2006). Comparison of measured and EF5-r derived $\mathrm{N} O$ fluxes from a spring-fed river. Global Change Biology, 12, 352-363.

Cooke, J. G. and White, R. E. (1987). The effect of nitrate in stream water on the relationship between gentrification and nitrification in a stream-sediment microcosm. Freshwater Biology, 18, 213-226.

Creed, I. F., Band, L. E., Foster, N. W. et al. (1996). Regulation of nitrate- $\mathrm{N}$ release from temperate forests: a test of the $\mathrm{N}$ flushing hypothesis. Water Resources Research, 32, 3337-3354.

Curtis, C. J., Emmett, B. A., Reynolds, B. and Shilland, J. (2006). How important is $\mathrm{N} 2 \mathrm{O}$ production in removing atmospherically deposited nitrogen from UK moorland catchments? Soil Biology \& Biochemistry, 38, 2081-2091.

Curtis, C. J., Evans, C. D., Helliwell, R. C. and Monteith, D. T. (2005). Nitrate leaching as a confounding factor in chemical recovery from acidification in UK upland waters. Environmental Pollution, 137, 73-82.

Dages, C., Voltz, M. and Ackerer, P. (2008). Parameterization and evaluation of a three-dimensional modelling approach to water table recharge from seepage losses in a ditch. Journal of Hydrology, $348,350-362$.

de Klein, J. (2008). From ditch to delta, nutrient retention in running waters. Ph.D. thesis, Wageningen University, Wageningen, The Netherlands, ISBN 978-90-8504-930-2.

Dhondt, K., Boeckx, P., Hofman, G. and Van Cleemput, O. (2004). Temporal and spatial patterns of denitrification enzyme activity and nitrous oxide fluxes in three adjacent vegetated riparian buffer zones. Biology and Fertility of Soils, 40, 243-251.

Dise, N. B., Ashmore, M., Belyazid, S. et al. (2011). Nitrogen as a threat to European terrestrial biodiversity. In: The European Nitrogen Assessment, ed. M. A. Sutton, C. M. Howard, J. W. Erisman et al., Cambridge University Press. 
Dong, L. F., Nedwell, D. B., Colbeck, I. and Finch, J. (2004). Nitrous oxide emission from some English and Welsh rivers and estuaries. Water, Air, \& Soil Pollution: Focus, 4, 127-134.

Dowdell, R. J., Burford, J. R. and Crees, R. (1979). Losses of nitrous oxide dissolved in drainage water from agricultural land. Nature, 278, 342-343.

Duarte, C. M. (1992). Nutrient concentration of aquatic plants: patterns across species. Limnology and Oceanography, 37, 882-889.

Durand, P. (2004). Simulating nitrogen budgets in complex farming systems using INCA: calibration and scenario analyses for the Kervidy catchment (W. France). Hydrology and Earth System Sciences, 8, 793-802.

Durand, P., Cros-Cayot, S., Gascuel-Odoux, C . and Heddadj, D. (1999). Solute concentrations of overland flow water in a cultivated field: spatial variations, intra- and inter-storm trends. Hydrological Processes, 13, 1465-1477.

Durand, P. and Juan Torres, J. L. (1996). Solute transfer in agricultural catchments: the interest and limits of mixing models. Journal of Hydrology, 181, 1-22.

Einsiedl, F., Maloszewski, P. and Stichler, W. (2005). Estimation of denitrification potential in a karst aquifer using the $15 \mathrm{~N}$ and $18 \mathrm{O}$ isotopes of NO3-. Biogeochemistry, 72, 67-86.

Elser, J. J., Bracken, M. E. S., Cleland, E. E. et al. (2007). Global analysis of nitrogen and phosphorus limitation of primary producers in freshwater, marine and terrestrial ecosystems. Ecology Letters, 10, $1135-1142$

Ensign, S. H. and Doyle, M. W. (2006). Nutrient spiraling in streams and river networks. Journal of Geophysical Research, 111, G04009, doi:10.1029/2005JG000114.

Evans, C. D., Monteith, D. T. and Cooper, D. M. (2005). Long-term increases in surface water dissolved organic carbon: observations, possible causes and environmental impacts. Environmental Pollution, 137, 55-71.

European Environment Agency (2005). The European environmentState and outlook 2005. Copenhagen, http://www.eea.europa.eu/, Surface coverage data, June 2010.

Fong, P., Fong, J. J. and Fong, C. R. (2004). Growth, nutrient storage, and release of dissolved organic nitrogen by Enteromorpha intestinalis in response to pulses of nitrogen and phosphorus. Aquatic Botany, 78, 83-95.

Foster, S. S. D., Bridge, L. R., Geake, A. K., Lawrence, A. R. and Parker, G. R. (1986). The groundwater nitrate problem. In Hydrogeology Report No 86/2, ed. Keyworth, British Geological Survey.

Garban, B., Ollivon, D., Poulin, M., Gaultier, V. and Chesterikoff, A. (1995). Exchanges at the sediment-water interface in the river Seine, downstream from Paris. Water Research, 29, 473-481.

Garnier, J., Billen, G. and Cebron, A. (2007). Modelling nitrogen transformations in the lower Seine river and estuary (France): impact of wastewater release on oxygenation and $\mathrm{N} 2 \mathrm{O}$ emission. Hydrobiologia, 588, 291-302.

Garnier, J., Billen, G. and Palfner, L. (1999). Understanding the oxygen budget and related ecological processes in the river Mosel: the RIVERSTRAHLER approach. Hydrobiologia, 410, 151-166.

Garnier, J., Billen, G., Vilain, G. et al. (2009). Nitrous oxide (N2O) in the Seine river and basin: observations and budgets. Agriculture, Ecosystems \& Environment, 133, 223-233.

Gonzalez Sagrario, M. A., Jeppesen, E., Goma, J. et al. (2005). Does high nitrogen loading prevent clear-water conditions in shallow lakes at moderately high phosphorus concentrations? Freshwater Biology, 50, 27-41.
Gooddy, D. C., Clay, J. W. and Bottrell, S. H. (2002). Redox-driven changes in porewater chemistry in the unsaturated zone of the chalk aquifer beneath unlined cattle slurry lagoons. Applied Geochemistry, 17, 903-921.

Green, C. T., Puckett, L. J., Bohlke, J. K. et al. (2008). Limited occurrence of denitrification in four shallow aquifers in agricultural areas of the United States. Journal of Environmental Quality, 37, 994-1009.

Grennfelt, P. and Hultberg, H. (1986). Effects of nitrogen deposition on the acidification of terrestrial and aquatic ecosystems. Water, Air, \& Soil Pollution, 30, 945-963.

Grizzetti, B., Bouraoui, F., Billen, G. et al. (2011). Nitrogen as a threat to European water quality. In: The European Nitrogen Assessment, ed. M. A. Sutton, C. M. Howard, J. W. Erisman et al., Cambridge University Press.

Haag, D. and Kaupenjohann, M. (2001). Landscape fate of nitrate fluxes and emissions in Central Europe. A critical review of concepts, data, and models for transport and retention. Agriculture, Ecosystems \& Environment, 86, 1-21.

Hasegawa, K., Hanaki, K., Matsuo, T. and Hidaka, S. (2000). Nitrous oxide from the agricultural water system contaminated with high nitrogen. Chemosphere - Global Change Science, 2, 335-345.

Haycock, N. E., Burt, T. P., Goulding, K. W. T. and Pinay, G. (1997). Buffer zones: their processes and potential in water protection. In The Proceedings of the International Conference on Buffer Zones, September 1996; Quest Environmental, Harpenden, Hertfordshire.

Hecky, R. E. and Kilham, P. (1988). Nutrient limitation of phytoplankton in freshwater and marine environments: a review of recent evidence on the effects of enrichment. Limnology and Oceanography, 33, 796-822.

Henriksen, A. and Brakke, D. F. (1988). Increasing contributions of nitrogen to the acidity of surface waters in Norway. Water Air and Soil Pollution, 42, 183-201.

Hilton, J., O’Hare, M., Bowes, M. J. and Jones, J. I. (2006). How green is my river? A new paradigm of eutrophication in rivers. Science of the Total Environment, 365, 66-83.

Howarth, R. W., Billen, G., Swaney, D. et al. (1996). Regional nitrogen budgets and riverine $\mathrm{N} \& \mathrm{P}$ fluxes for the drainages to the North Atlantic Ocean: natural and human influences. Biogeochemistry, 35, 75-139.

Huszar, V. L. M., Caraco, N. F., Roland, F. and Cole, J. (2006). Nutrient-chlorophyll relationships in tropical-subtropical lakes: do temperate models fit? Biogeochemistry, 79, 239-250.

Huttunen, J. T., Juutinen, S., Alm, J. et al. (2003). Nitrous oxide flux to the atmosphere from the littoral zone of a boreal lake. Journal of Geophysical Research, 108, 4421. doi:10.1029/2002JD002989.

International Committee Lake Foundation (2010). World Lakes Database, http://www.ilec.or.jp, June 2010.

Jackson, B. M., Browne, C. A., Butler, A. P. et al. (2008). Nitrate transport in Chalk catchments: monitoring, modelling and policy implications. Environmental Science \& Policy, 11, 125-135.

Jackson, B. M., Wheater, H. S., Wade, A. J. et al. (2007). Catchmentscale modelling of flow and nutrient transport in the Chalk unsaturated zone. Ecological Modelling, 209, 41-52.

James, C., Fisher, J. and Moss, B. (2003). Nitrogen driven lakes: The Shropshire and Cheshire Meres? Archiv für Hydrobiologie, 158, 249-266.

James, C., Fisher, J., Russel, V., Collings, S. and Moss, B. (2005). Nitrate availability and hydrophyte species richness in shallow lakes. Freshwater Biology, 50, 1049-1063. 
Jeppesen, E., Sondergaard, M., Jensen, J. P. et al. (2005). Lake responses to reduced nutrient loading-an analysis of contemporary long-term data from 35 case studies. Freshwater Biology, 50, 1747-1771.

Johansson, A. E., Klemedtsson, K., Klemedtsson, L. and Svensson, B. H. (2003). Nitrous oxide exchanges with the atmosphere of a constructed wetland treating wastewater. Tellus $B, 55,737-750$.

Johnes, P. J. (2007a). Meeting ecological restoration targets in European waters: a challenge for animal agriculture. In: Redesigning Animal Agriculture, ed. D. Swain, E. Charmley, J. Steel and S. Coffey, Wallingford: CAB International, Chapter 11, pp. 185-203.

Johnes, P. J. (2007b). Uncertainties in annual riverine phosphorus load estimation: Impact of load estimation methodology, sampling frequency, baseflow index and catchment population density. Journal of Hydrology, 332, 241-258.

Johnes, P. J. and Burt, T. P. (1991). Water quality trends in the Windrush catchment: nitrogen speciation and sediment interactions. IAHS Publication, 203, 349-357.

Johnes, P. J. and Butterfield, D. (2002). Landscape, regional and global estimates of nitrogen flux from land to ocean: errors and uncertainties. Biogeochemistry, 57/58, 429-476.

Johnson, D., Fletcher, S. W. and Bray, K. (2007). Integrated assessment of nitrate concentrations for the designation of groundwater Nitrate Vulnerable Zones in England and Wales. Quarterly Journal of Engineering Geology \& Hydrogeology, 40, 407.

Johnston, C. A., Detenbeck, N. E. and Niemi, G. J. (1990). The cumulative effect of wetlands on stream water quality and quantity. A landscape approach. Biogeochemistry, 10, 105-141.

Jones, D. L., Healey, J. R., Willett, V. B., Farrar, J. F. and Hodge, A. (2005). Dissolved organic nitrogen uptake by plantsùan important $\mathrm{N}$ uptake pathway? Soil Biology \& Biochemistry, 37, 413-423.

Kaste, Ø., de Wit, H., Skjelkvåle, B. L. and Høgåsen, T. (2007). Nitrogen runoff at ICP Waters sites 1990-2005: Increasing importance of confounding factors? In: Trends in surface water chemistry and biota. The importance of confounding factors ICP Waters report 87/2007. NIVA serial.no. 5385, ed. H. de Wit and B. L. Skjelkvåle, pp. 29-38.

Kelly, C. A., Rudd, J. W. M., Hesslein, R. H. et al. (1987). Prediction of biological acid neutralization in acid-sensitive lakes. Biogeochemistry, 3, 129-140.

Kemp, M. J. and Dodds, W. K. (2001). Spatial and temporal patterns of nitrogen concentrations in pristine and agriculturally-influenced prairie streams. Biogeochemistry, 53, 125-141.

Kinniburgh, D. G., Gale, I. N., Gooddy, D. C. et al. (1999). Denitrification in the unsaturated zones of the British Chalk and Sherwood Sandstone aquifers. British Geological Survey Technical Report, WD/99/2.

Kölle, W., Strebel, O. and Böttcher, J. (1985). Formation of sulphate by microbial denitrification in a reducing aquifer. Water Supply, 3, 35-40.

Korom, S. F. (1992). Natural denitrification in the saturated zone: a review. Water Resourc. Res., 28, 1657-1668.

Kortelainen, P., Mattsson, T., Finer, L. et al. (2006). Controls on the export of $\mathrm{C}, \mathrm{N}, \mathrm{P}$ and $\mathrm{Fe}$ from undisturbed boreal catchments, Finland. Aquatic Sciences-Research Across Boundaries, 68, 453-468.

Kortelainen, P., Saukkonen, S. and Mattsson, T. (1997). Leaching of nitrogen from forested catchments in Finland. Global Biogeochemical Cycles, 11, 627-638.

Kroeze, C., Mosier, A. and Bouwman, L. (1999). Closing the global N2O budget: a retrospective analysis 1500-1994. Global Biogeochemical Cycles, 13, 1-8.
Lipson, D. and Näsholm, T. (2001). The unexpected versatility of plants: organic nitrogen use and availability in terrestrial ecosystems. Oecologia, 128, 305-316.

Maberly, S. C., King, L., Dent, M. M., Jones, R. I. and Gibson, C. E. (2002). Nutrient limitation of phytoplankton \& periphyton growth in upland lakes. Freshwater Biology, 47, 2136-2152.

MacMahon, P. B. and Dennehy, K. F. (1999). N2O emissions from a nitrogen-enriched river. Environmental Science \& Technology, 22, $21-25$.

Marti, E., Aumatell, J., Gode, L., Poch, M. and Sabater, F. (2004). Nutrient retention efficiency in streams receiving inputs from wastewater treatment plants. Journal of Environmental Quality, 33, 285-293.

Martin, C., Molenat, J., Gascuel-Odoux, C. et al. (2006). Modelling the effect of physical and chemical characteristics of shallow aquifers on water and nitrate transport in small agricultural catchments. Journal of Hydrology, 326, 25-42.

Mattsson, T., Finér, L., Kortelainen, P. and Sallantaus, T. (2003). Brook water quality and background leaching from unmanaged forested catchments in Finland. Water Air and Soil Pollution, 147, 275-297.

Mattsson, T., Kortelainen, P., Laubel, A. et al. (2009). Export of dissolved organic matter in relation to land use along a European climatic gradient. Science of the Total Environment, 407, 1967-1976.

McClain, M. E., Boyer, E. W., Dent, C. L. et al. (2003). Biogeochemical hot spots and hot moments at the interface of terrestrial and aquatic ecosystems. Ecosystems, 6, 301-312.

Mengis, M., Gächter, R. and Wehrli, B. (1997). Sources and sinks of nitrous oxide (N2O) in deep lakes. Biogeochemistry, 38, 281-301.

Mermillod-Blondin, F., Mauclaire, L. and Montuelle, B. (2005). Use of slow filtration columns to assess oxygen respiration, consumption of dissolved organic carbon, nitrogen transformations, and microbial parameters in hyporheic sediments. Water Research, 39, $1687-1698$.

Merrix, F. L., Lewis, B. R. and Ormerod, S. J. (2006). The effects of low $\mathrm{pH}$ and palliative liming on beech litter decomposition in acidsensitive streams. Hydrobiologia, 571, 373-381.

Molenat, J., Durand, P., Gascuel-Odoux, C., Davy, P. and Gruau, G. (2002). Mechanisms of nitrate transfer from soil to stream in an agricultural watershed of French Brittany. Water Air and Soil Pollution, 133, 161-183.

Monteith, D. T., Evans, C. D. and Reynolds, B. (2000). Are temporal variations in the nitrate content of UK upland freshwaters linked to the North Atlantic Oscillation? Hydrological Processes, 14, $1745-1749$.

Moss, B., Johnes, P. J. and Phillips, G. L. (1996). The monitoring and classification of standing waters in temperate regions - a discussion and proposal based on a worked scheme for British waters. Biological Reviews, 71, 310-339.

Mulligan, D., Bauraoui, F., Grizzetti, B., Aloe, A. and Dusart, J. (2006). An atlas of pan-European data for investigating the fate of agrochemicals in terrestrial ecosystems. In $22334 \mathrm{EN}$, ed.

Murdoch, P. S. and Stoddard, J. L. (1992). The role of nitrate in the acidification of streams in the Catskill Mountains of New York. Water Resources Research, 28, 2707-2720.

Neilsen, M. E., Fisk, M. R., Istok, J. D. and Pedersen, K. (2006). Microbial nitrate respiration of lactate at in situ conditions in ground water from a granitic aquifer situated $450 \mathrm{~m}$ underground. Geobiology, 4, 43-52.

Nixon, S. W., Ammerman, J. W., Atkinson, L. P. et al. (1996). The fate of nitrogen and phosphorus at the land sea margin of the North Atlantic Ocean. Biogeochemistry, 35, 141-180. 
Oenema, O., Oudendag, D. and Velthof, G. L. (2007). Nutrient losses from manure management in the European Union. Livestock Science, 112, 261-272.

Ormerod, S. J. and Durance, I. (2009). Restoration and recovery from acidification in upland Welsh streams over 25 years. Journal of Ecology, 46, 164-174.

Phillips, G., Pietiläinen, O. P., Carvalho, L. et al. (2008). Chlorophyllnutrient relationships of different lake types using a large European dataset. Aquatic Ecology, 42, 213-226.

Pinay, G., Clement, J. C. and Naiman, R. J. (2002). Basic principles and ecological consequences of changing water regimes on nitrogen cycling in fluvial systems. Environmental Management, 30, 481-491.

Pinay, G., Decamps, H., Arles, C. and Lacassin-Seres, M. (1989). Topographic influence on carbon and nitrogen dynamics in riverine woods. Archiv für Hydrobiologie, 114, 404-414.

Prechtl, J., Kneip, C., Lockhart, P., Wenderoth, K. and Maier, U. G. (2004). Intracellular spheroid bodies of Rhopalodia gibba have nitrogen-fixing apparatus of cyanobacterial origin. Molecular biology and evolution, 21, 1477-1481.

Prior, H. and Johnes, P. J. (2002). Regulation of surface water quality in a Cretaceous Chalk catchment, UK: an assessment of the relative importance of instream and wetland processes. Science of the Total Environment, 282, 159-174.

Regina, K., Nykänen, H., Silvola, J. and Martikainen, P. J. (1996). Fluxes of nitrous oxide from boreal peatlands as affected by peatland type, water table level and nitrification capacity. Biogeochemistry, 35, 401-418.

Rekolainen, S., Mitikka, S., Vuorenmaa, J. and Johansson, M. (2004). Rapid decline of dissolved nitrogen in Finnish lakes. Journal of Hydrology, 304, 94-102, doi:10.1016/j.hydrol.2004.07.024.

Revsbech, N. P., Jacobsen, J. P. and Nielsen, L. P. (2005). Nitrogen transformations in microenvironments of river beds and riparian zones. Ecological Engineering, 24, 447-455.

Reynolds, B. and Edwards, A. (1995). Factors influencing dissolved nitrogen concentrations and loadings in upland streams of the UK. Agricultural Water Management, 27, 181-202.

Rivett, M. O., Smith, J. W. N., Buss, S. R. and Morgan, P. (2007). Nitrate occurrence and attenuation in the major aquifers of England and Wales. Quarterly Journal of Engineering Geology \& Hydrogeology, 40, 335-352.

Rivett, M. O., Buss, S. R., Morgan, P., Smith, J. W. N. and Bemment, C. D. (2008). Nitrate attenuation in groundwater: a review of biogeochemical controlling processes. Water Research, 42, 4215-4232.

Rogora, M. and Mosello, R. (2007). Climate as a confounding factor in the response of surface water to nitrogen deposition in an area south of the Alps. Applied Geochemistry, 22, 1122-1128.

Ruckart, P. Z., Henderson, A. K., Black, M. L. and Flanders, W. D. (2007). Are nitrate levels in groundwater stable over time? Journal of Exposure Science and Environmental Epidemiology, 18, 129-133.

Sabater, S., Butturini, A., Clement, J. C. et al. (2003). Nitrogen removal by riparian buffers along a European climatic gradient: patterns and factors of variation. Ecosystems, 6, 20-30.

Sanchez, N. (1996). Le processus de dénitrification dans les sédiments du barrage-réservoir de la Marne: Etude de sa cinétique et modélisation. Ph.D. thesis. University Pierre et Marie Curie, Paris.

Schelske, C. L. and Stoermer, E. F. (1971). Eutrophication, silica depletion, and predicted changes in algal quality in Lake Michigan. Science, 173, 423-424.
Seitzinger, S., Harrison, J. A., Bohlke, J. K. et al. (2006). Denitrification across landscapes and waterscapes: A synthesis. Ecological Applications, 16, 2064-2090.

Seitzinger, S. P. and Kroeze, C. (1998). Global distribution of nitrous oxide production and $\mathrm{N}$ inputs in freshwater and coastal marine ecosystems. Global Biogeochemical Cycles, 12, 93-113.

Seitzinger, S. P. and Sanders, R. W. (1997). Contribution of dissolved organic nitrogen from rivers to estuarine eutrophication. Marine Ecology-Progress Series, 159, 1-12.

Seitzinger, S. P., Styles, R. V., Boyer, E. W. et al. (2002). Nitrogen retention in rivers: model development and application to watersheds in the northeastern USA. Biogeochemistry, 57, 199-237.

Siemens, J. (2003). The European carbon budget: a gap. Science, 302, 1681.

Skoulikidis, N. and Amaxidis, Y. (2009). Origin and dynamics of dissolved and particulate nutrients in a minimally disturbed Mediterranean river with intermittent flow. Journal of Hydrology, 373, 218-229.

Smith, J. W. N. and Lerner, D. N. (2008). Geomorphologic control on pollutant retardation at the groundwater-surface water interface. Hydrological Processes, 22, 4679-4694.

Søvik, A. K., Augustin, J., Heikkinen, K. et al. (2006). Emission of the greenhouse gases nitrous oxide and methane from constructed wetlands in Europe. Journal of Environmental Quality, 35, 2360-2373.

Strahler, A. N. (1952). Hypsometric (area-altitude) analysis of erosional topography. Bulletin of the Geological Society of America, 63, 1117-1142.

Tallec, G., Garnier, J., Billen, G. and Gousailles, M. (2006). Nitrous oxide emissions from secondary activated sludge in nitrifying conditions of urban wastewater treatment plants: effect of oxygenation level. Water Research, 40, 2972-2980.

Talling, J. F. (1979). Factor interactions and implications for the prediction of lake metabolism. Archiv für Hydrobiologie, 13, 96-109.

Thayalakumaran, T., Bristow, K. L., Charlesworth, P. B. and Fass, T. (2007). Geochemical conditions in groundwater systems: implications for the attenuation of agricultural nitrate. Agricultural Water Management, 95, 103-115.

Thouvenot, M., Billen, G. and Garnier, J. (2007). Modelling nutrient exchange at the sediment-water interface of river systems. Journal of Hydrology, 341, 55-78.

Van der Molen, D. T., Portielje, R., De Nobel, W. T. and Boers, P. C. M. (1998). Nitrogen in Dutch freshwater lakes: trends and targets. Environmental Pollution, 102, 553-557.

Verhoeven, J. T. A., Keuter, A., Van Logtestijn, R., van Kerkhoven, M. B. and Wassen, M. (1996). Control of local nutrient dynamics in mires by regional and climatic factors: A comparison of Dutch and Polish sites. Journal of Ecology, 84, 647-656.

Wade, A. J., Butterfield, D. and Whitehead, P. G. (2006). Towards an improved understanding of the nitrate dynamics in lowland, permeable river-systems: Applications of INCA-N. Journal of Hydrology, 330, 185-203.

Willetts, V. B., Reynolds, B. A., Stevens, P. A., Ormerod, S. J. and Jones, D. L. (2004). Dissolved organic nitrogen regulation in freshwaters. Journal of Environmental Quality, 33, 201-209.

Wright, R. F., Alewell, C., Cullen, J. M. et al. (2001). Trends in nitrogen deposition and leaching in acid-sensitive streams in Europe. Hydrology and Earth System Sciences, 5, 299-31. 